\title{
Normal and abnormal follicular growth in mouse, rat and human ovaries
}

\author{
R. G. Edwards, R. E. Fowler, R. E. Gore-Langton, R. G. Gosden, \\ E. C. Jones*, C. Readhead and P. C. Steptoe† \\ Physiological Laboratory, Cambridge, * Department of Anatomy, Birmingham, and \\ $\dagger$ Oldham \& District General Hospital, Lancashire, U.K.
}

We wish to present an analysis of the data gained by a group of workers studying various aspects of ovarian activity. Our work has been concerned primarily with two aspects of the development of follicles: the initiation and control of follicular growth, and differentiation and steroidogenesis in follicles approaching ovulation. The scope of our contributions spans the lifetime of the female from the early stages of growth in the fetal ovary to the final stages of follicular development in ageing females and includes both animal and clinical studies. The results are given in two main sections: follicular growth, and normal and abnormal differentiation and steroidogenesis in follicles approaching ovulation. Several aspects of follicular growth are considered in the discussion.

\section{Follicular growth}

\section{Is there a regularity in the formation and utilization of follicles?}

A full understanding of follicular growth in the adult ovary cannot be gained until the factors governing the establishment of follicles in the immature ovary are clarified. Plentiful evidence has shown how follicles are formed in gradients in the fetal or neonatal ovary; small follicles containing an oocyte in dictyotene are identified in some areas of the cortical cords, whereas oocytes still in early prophase of meiosis or oogonia in mitosis can be found in other areas. We suspect that this sequential formation of follicles is reflected in their future utilization in the adult female as they begin growth at various times during the lifespan. Such regularity in the formation and utilization of follicles was suggested by the results of studies on chiasma frequency in oocytes and spermatocytes taken from mice of different ages (Henderson \& Edwards, 1968). A steady decline was found in the number of chiasmata in oocytes, and chiasma position became located towards the ends of the chromosomes as the female aged (Text-fig. 1). Since chiasmata are formed in the fetal ovary, this observation implied that oocytes with few chiasmata were conserved until the end of the reproductive life of the female. An objection to this conclusion is that chiasma position may become terminalized during the prolonged dictyotene stage, although the existence of this process has been questioned (Henderson, 1970). There was no decline in the number of chiasmata in spermatocytes with increasing age in males.

An alternative method was needed to confirm that certain oocytes were conserved until the end of the reproductive life of the female. One approach is to study the recombination frequency of linked marker genes in offspring of ageing parents. The position of chiasmata and the position of recombination on the chromosome are believed to be closely associated, hence the reduction noted in chiasma frequency in oocytes with increasing maternal age should be associated with fewer recombinants in offspring of ageing female mice. A group of linked marker genes on chromosome 2 of the mouse was therefore used to study recombination frequency with increasing parental age, by using backcrosses to heterozygous females or heterozygous males to test for recombination in mothers and fathers respectively (Wallace, MacSwiney \& Edwards, 1976). In the strain of mouse studied, a great 


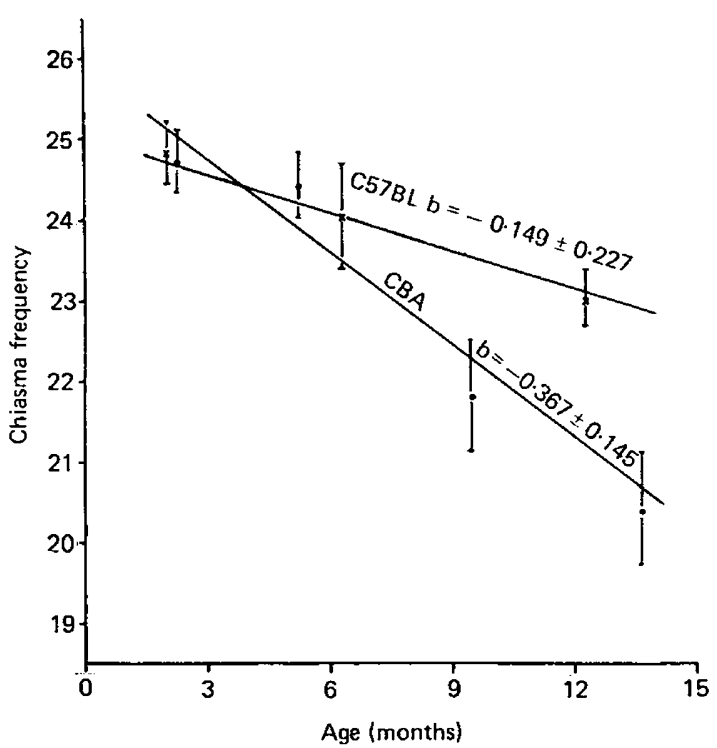

Text-fig. 1. The chiasma frequency in oocytes of inbred mice with increasing maternal age. (Reproduced by permission from Henderson \& Edwards, 1968.)

length of chromosome No. 2 was covered by linked marker genes which served to identify many recombinants occurring along most of the chromosome:

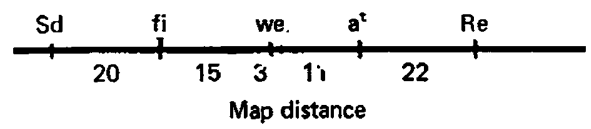

The breeding programme was analysed to find out if differences existed between ageing males and ageing females as indicated by the studies on chiasma frequency. The analysis of recombination frequency indicates that some conclusions on chiasma frequency may be confirmed, at least tentatively. Analysis of offspring from ageing females showed that the number of recombinants did decline with increasing age, although the trend was not statistically significant (Table 1). Unfortunately, females become infertile at those advanced ages at which more data are needed, leading to

Table 1. Recombinations in the offspring of ageing male and female mice (data from Wallace et al., 1977)

\begin{tabular}{ccccc}
\hline & $\begin{array}{c}\text { Age of } \\
\text { parent } \\
\text { (months) }\end{array}$ & $\begin{array}{c}\text { No. of } \\
\text { offspring }\end{array}$ & $\begin{array}{c}\text { Mean no. of } \\
\text { recombinants } \\
\text { per offspring }\end{array}$ & $\begin{array}{c}\text { Proportion of } \\
\text { offspring with } \\
\text { no recombinants }\end{array}$ \\
\hline Mother & $<3$ & 150 & 0.86 & 0.50 \\
& $3-4$ & 130 & 0.91 & 0.37 \\
& $4-6$ & 255 & 0.78 & 0.69 \\
& $6-8$ & 129 & 0.88 & 0.40 \\
Father & $8-10$ & 48 & 0.79 & 0.71 \\
& $>10$ & 18 & 0.72 & 0.80 \\
& $<3$ & 183 & 0.81 & 0.51 \\
& $6-8$ & 464 & 0.81 & 0.49 \\
\hline
\end{tabular}

There was no significant heterogeneity between groups (heterogeneity $\left.\chi^{2} P>0.05\right)$ except in offspring with no recombinants compared with the age of mother $(P<0.05)$. 
difficulties in obtaining large numbers of offspring in such a mating programme. One parameter was significant: many offspring were found to have no detectable recombinants, and there was a significant heterogeneity $\chi^{2}$ in the distribution of these offspring with age of the mother (Table 1), although this heterogeneity was evidently not due to a linear trend with age. The absence of recombinants in the offspring implies that recombination had occurred at the end of the chromosome, i.e. outside the region covered by the marker genes (Text-fig. 2), or that a double recombination had occurred between two of the marker genes and was undetectable. Terminal recombinations would be expected from the observations on the position of chiasmata in oocytes, for many of them were also found in a terminal position in oocytes of ageing females. The two methods of analysis may therefore be giving similar conclusions.
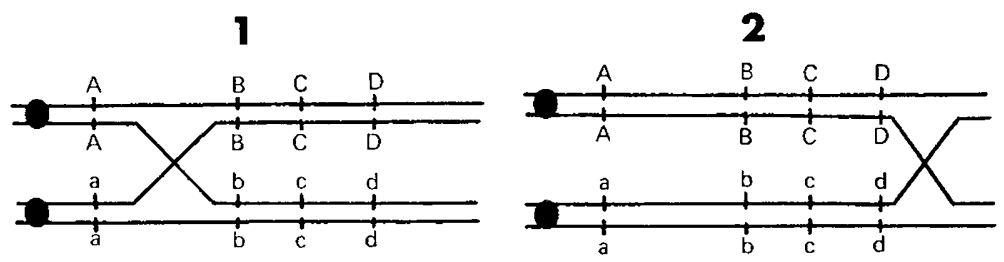

Text-fig. 2. Diagram indicating why recombinants at the terminal end of chromosome 2 would not be detected. In Example 1, recombination between A and B would be detected; in Example 2, the recombinant would not be recorded because it occurs outside the area covered by the marker genes.

Establishing such a linkage analysis over the lifetime involves a long-term programme, and the imitation arising through the decline in natural fertility at about 12 months will have to be overcome by transferring blastocysts from ageing mothers into young recipients. This method should provide data from those mothers of greatest interest to us, namely those aged $1 \frac{1}{2}$ or 2 years, when the number of recombinations should be very low if our hypothesis is correct. It is interesting to note that no trend or heterogeneity was found in analyses carried out on the offspring of ageing males (Table 1).

\section{Dynamics of follicular growth throughout life in intact and hypophysectomized mice}

Detailed quantitative analyses have been carried out on populations of oocytes and follicles at different stages of development in mice of all ages, from neonates to the aged adult. The data were initially obtained during studies on the effects of increasing age on the number of oocytes and follicles in normal and hypophysectomized females (Jones \& Krohn, 1961a, b). Ovaries from 54 normal virgin mice aged 0-560 days and 12 hypophysectomized mice aged 52-505 days were sectioned serially and follicles were counted and classified into groups which have been described elsewhere (Zuckerman, 1951). Follicles were included in the count if the section passed through the nucleolus of the oocyte and, since the difference between 1:5 and 1:10 samples was statistically insignificant, every 10th section was scanned and the observed estimate for each follicle group was multiplied by 10. The accuracy of this estimation method will clearly decrease with increasing size of follicle and when more precise determination of numbers of large follicles was required every section was examined. Oocytes still in the pre-dictyate stage and lacking a nucleolar marker were included if the section was judged to contain half, or more, of the nucleus. A correction factor to allow for overcounting (Abercrombie, 1946) was applied to the estimates of primordial follicles except for old ovaries in which the total number of follicles is low and every section was scanned. An attempt was made to distinguish between normal and atretic follicles by histological criteria. The appearance of the nucleus, cytoplasm and membranes of the oocyte, and of the surrounding granulosa cells was taken into account. Such subjective diagnosis of atresia in large follicles was relatively straightforward but became more uncertain with decrease in size.

These data have been used to test models of follicular utilization (Faddy, Jones \& Edwards, 1976). Analysing follicle turnover in relation to time spent in different developmental stages is not easy, even though the pulse labelling of DNA has given invaluable information on mitosis in follicle 
cells and on follicular growth (Pedersen, 1972). Designing a mathematical model which can be tested against data on ovarian contents is useful because the whole spectrum of activity in follicles beginning their growth, dying and leaving or entering various phases in development must be quantified and explained.

In mice, utilization from the pool of primordial follicles begins soon after birth, Group II follicles being found at 3 days, and Group III with two layers of granulosa cells at 5 days (Pl. 1, Fig. 1). Follicles thus migrate forwards through these and other groups towards ovulation, although many die at various stages of development. Since there is no new formation of oocytes after birth, a mathematical model of the 'death/migration' type would be appropriate (Faddy, 1976). In this model (Text-fig. 3) the number of follicles present in each group at any age is represented by independent Poisson counts whose means can be compared at various ages to gain information on follicle turnover. The essential characteristics that must be determined are the migration $(v)$ and death $(\mu)$ rates of each type of follicle.

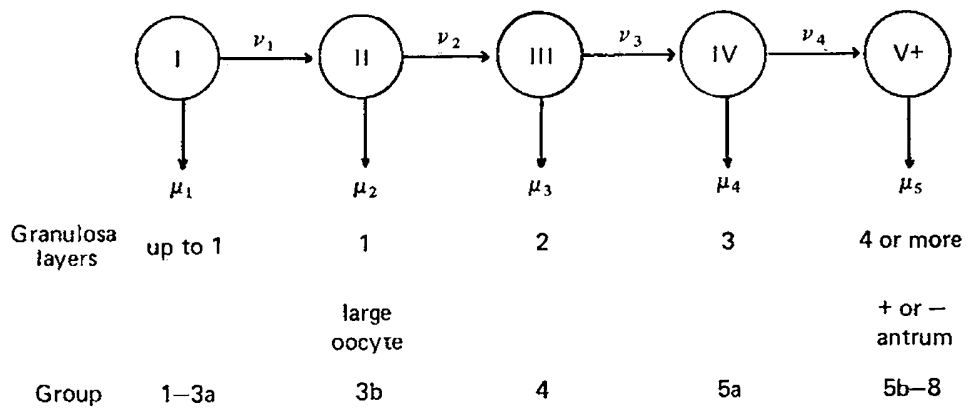

Text-fig. 3. A death/migration model of follicular dynamics. The stages of development in terms of layers of granulosa cells are shown, together with a comparison of the classification groups used by Pedersen \& Peters (1968). $\mu_{5}$ includes death in Group V+ and those follicles proceeding to ovulation. (From Faddy et al., 1976.)

In the initial analyses, migration and death rates were held to be constant for each follicle type throughout the lifespan, but the predicted curves did not fit the observed data. Some age dependence was then built into these rates. We had no clues from the data to such an age dependency and assumed that each transition rate of each follicle type was one constant between the ages of 0 and 30 days, i.e. in immature females, and another constant after 30 days. Nineteen parameters had thus to be estimated, the initial mean size of the pool (Group I) and a migration and death rate for each subsequent follicle group both before and after $\mathbf{3 0}$ days (as shown in Text-fig. 4). The estimates of utilization of

(a)

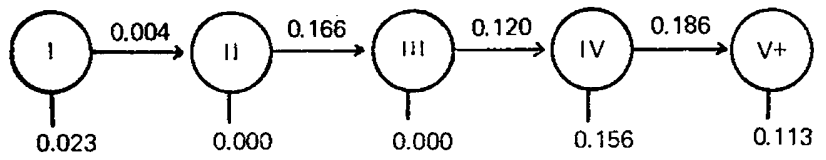

(b)

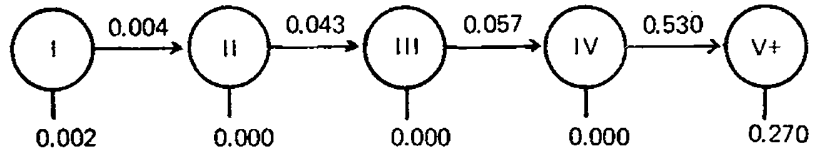

(c)

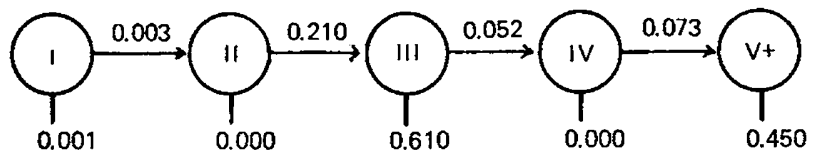

Text-fig. 4. Estimates of the daily death and migration rates of follicles of mice. (a) Intact mice before 30 days of age; (b) intact mice after 30 days; (c) mice hypophysectomized after 30 days of age. Death rates given as 0.000 were $<10^{-6}$. (From Faddy et al., 1976.) 
(a)
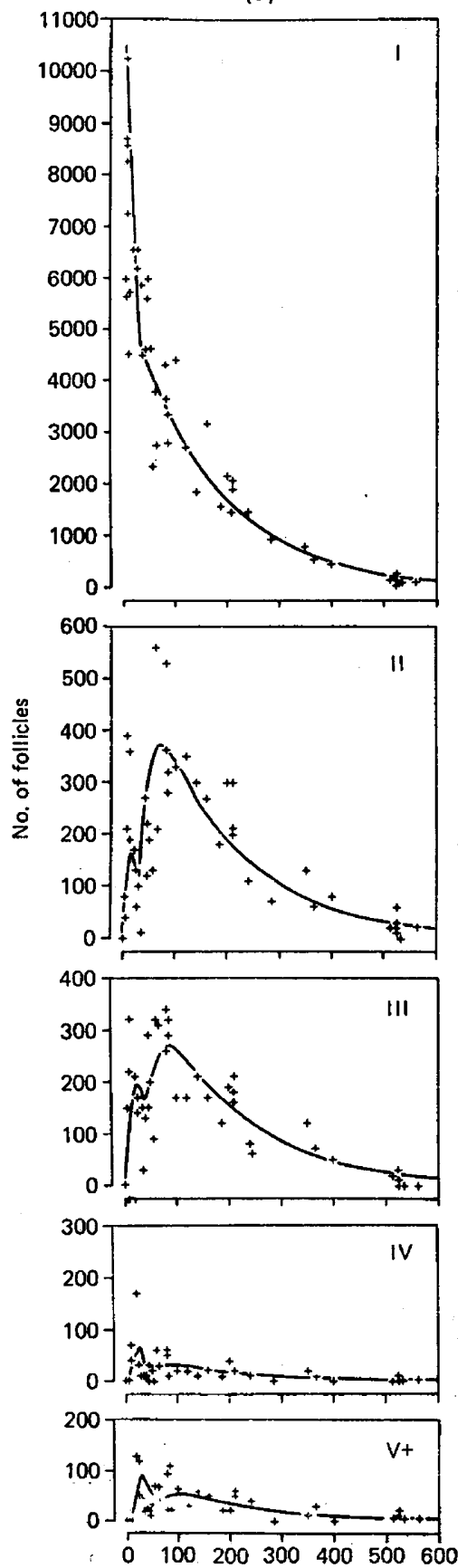

(b)

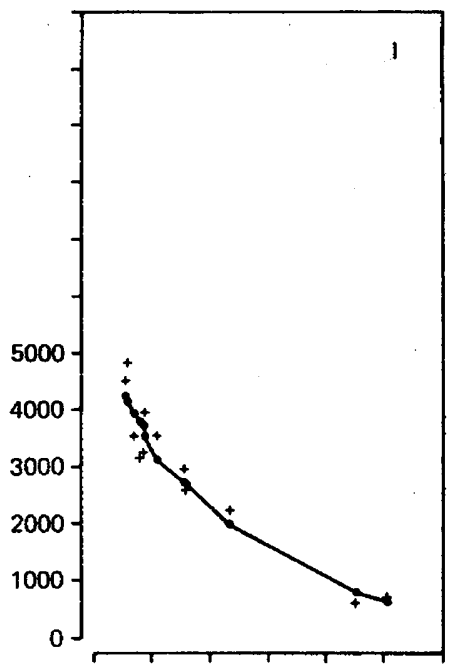

11

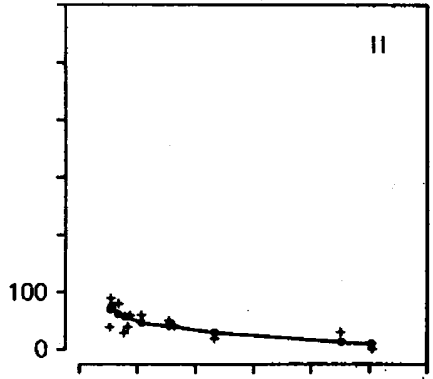

III
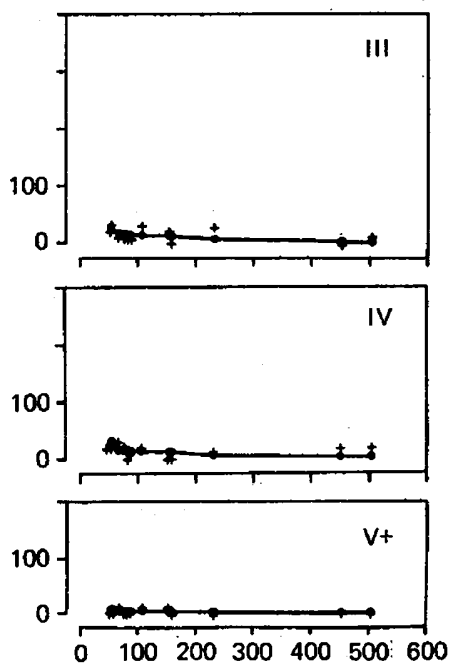

Age in days

Text-fig. 5. Predictions from the ovarian model (solid lines) in relation to the observed values $(+)$ of the number of follicles in mice (a) intact from Day 0 , (b) hypophysectomized after 30 days. Follicle groups are indicated. (From Faddy et al., 1976.) 
follicles throughout life in intact females that were finally achieved from the fitted model are shown in Table 2. This model now gives realistic predictions. For example, the calculated mean pool size of Group $I$ is about 10,500 which agrees fairly closely with estimates from the observed data. Biphasic peaks were observed in all other follicle groups and predictions from the model accord with this observation (Text-fig. 5).

The mean time which follicles spend in various groups at different ages can also be calculated. Some medium-sized follicles with up to two layers of granulosa cells appear to spend a longer mean time in these developmental stages than others of similar size, particularly in females aged more than

Table 2. Mean numbers of follicles (from fitted model) leaving and entering the five groups at specific intervals throughout life in (a) normal Strong A females (mean size of Group $I$ at age 0 days $=10,504$ ) and (b) Strong $A$ females hypophysectomized at 40 days of age. (Reproduced by permission from Faddy et al. 1976.)

\begin{tabular}{|c|c|c|c|c|c|c|c|c|c|c|}
\hline & \multirow{2}{*}{$\begin{array}{c}\text { Age-span } \\
\text { (days) }\end{array}$} & \multicolumn{9}{|c|}{ Groups* } \\
\hline & & $\mathrm{I} \rightarrow$ & $\rightarrow$ II & $\mathrm{II} \rightarrow$ & $\rightarrow$ III & III $\rightarrow$ & $\rightarrow I V$ & IV $\rightarrow$ & $\rightarrow \mathrm{V}+$ & $\mathrm{V}+\rightarrow$ \\
\hline \multirow[t]{20}{*}{ (a) } & $0-30$ & $5814 \cdot 1$ & $781 \cdot 6$ & $661 \cdot 6$ & $661 \cdot 6$ & 476.2 & $476 \cdot 2$ & $410 \cdot 4$ & $223 \cdot 2$ & $131 \cdot 0$ \\
\hline & $30-60$ & $773 \cdot 2$ & $559 \cdot 3$ & $340 \cdot 1$ & $340 \cdot 1$ & $313 \cdot 2$ & $313 \cdot 2$ & $356 \cdot 5$ & $356 \cdot 5$ & $406 \cdot 3$ \\
\hline & $60-90$ & $645 \cdot 7$ & 467.0 & $458 \cdot 1$ & $458 \cdot 1$ & 413.8 & 413.8 & $408 \cdot 5$ & $408 \cdot 5$ & $396 \cdot 8$ \\
\hline & $90-120$ & $539 \cdot 2$ & 390.0 & $429 \cdot 8$ & $429 \cdot 8$ & $439 \cdot 2$ & $439 \cdot 2$ & $440 \cdot 0$ & $440 \cdot 0$ & $440 \cdot 4$ \\
\hline & $120-150$ & $450 \cdot 3$ & $325 \cdot 7$ & $371 \cdot 8$ & $371 \cdot 8$ & $401 \cdot 6$ & $401 \cdot 6$ & $404 \cdot 8$ & $404 \cdot 8$ & 410.7 \\
\hline & $150-180$ & $376 \cdot 1$ & $272 \cdot 0$ & $314 \cdot 0$ & $314 \cdot 0$ & $346 \cdot 5$ & $346 \cdot 5$ & $350 \cdot 0$ & $350 \cdot 0$ & $357 \cdot 0$ \\
\hline & $180-210$ & $314 \cdot 1$ & $227 \cdot 2$ & $263 \cdot 2$ & $263 \cdot 2$ & $292 \cdot 7$ & $292 \cdot 7$ & 295.9 & 295.9 & $302 \cdot 4$ \\
\hline & $210-240$ & $262 \cdot 3$ & $189 \cdot 7$ & $220 \cdot 0$ & $220 \cdot 0$ & $245 \cdot 4$ & $245 \cdot 4$ & $248 \cdot 2$ & $248 \cdot 2$ & $253 \cdot 6$ \\
\hline & $240-270$ & $219 \cdot 0$ & $158 \cdot 4$ & 183.8 & $183 \cdot 8$ & $205 \cdot 2$ & $205 \cdot 2$ & $207 \cdot 5$ & $207 \cdot 5$ & $212 \cdot 2$ \\
\hline & $270-300$ & 182.9 & $132 \cdot 3$ & $153 \cdot 5$ & $153 \cdot 5$ & $171 \cdot 4$ & $171 \cdot 4$ & $173 \cdot 4$ & $173 \cdot 4$ & $177 \cdot 4$ \\
\hline & $300-330$ & $152 \cdot 8$ & $110 \cdot 5$ & $128 \cdot 2$ & $128 \cdot 2$ & $143 \cdot 2$ & $143 \cdot 2$ & $144 \cdot 8$ & $144 \cdot 8$ & $148 \cdot 1$ \\
\hline & $330-360$ & $127 \cdot 6$ & $92 \cdot 3$ & $107 \cdot 1$ & $107 \cdot 1$ & $119 \cdot 6$ & $119 \cdot 6$ & 121.0 & 121.0 & 123.8 \\
\hline & $360-390$ & $106 \cdot 5$ & $77 \cdot 1$ & 89.4 & $89 \cdot 4$ & 99.9 & 99.9 & $101 \cdot 0$ & 101.0 & $103 \cdot 3$ \\
\hline & $390-420$ & $89 \cdot 0$ & $64 \cdot 4$ & $74 \cdot 7$ & $74 \cdot 7$ & 83.4 & $83 \cdot 4$ & 84.4 & 84.4 & $86 \cdot 3$ \\
\hline & $420-450$ & $74 \cdot 3$ & $53 \cdot 7$ & $62 \cdot 4$ & $62 \cdot 4$ & $69 \cdot 6$ & $69 \cdot 6$ & $70 \cdot 5$ & $70 \cdot 5$ & $72 \cdot 1$ \\
\hline & $450-480$ & $62 \cdot 1$ & $44 \cdot 9$ & $52 \cdot 1$ & $52 \cdot 1$ & $58 \cdot 2$ & $58 \cdot 2$ & 58.8 & $58 \cdot 8$ & $60 \cdot 2$ \\
\hline & $480-510$ & $51 \cdot 8$ & $37 \cdot 5$ & $43 \cdot 5$ & $43 \cdot 5$ & $48 \cdot 6$ & $48 \cdot 6$ & $49 \cdot 1$ & $49 \cdot 1$ & $50 \cdot 2$ \\
\hline & $510-540$ & $43 \cdot 3$ & $31 \cdot 3$ & $36 \cdot 3$ & $36 \cdot 3$ & $40 \cdot 6$ & $40 \cdot 6$ & $41 \cdot 0$ & $41 \cdot 0$ & $41 \cdot 9$ \\
\hline & $540-570$ & $36 \cdot 1$ & $26 \cdot 1$ & $30 \cdot 3$ & $30 \cdot 3$ & 33.9 & 33.9 & $34 \cdot 3$ & $34 \cdot 3$ & $35 \cdot 1$ \\
\hline & $570-600$ & $30 \cdot 2$ & $21 \cdot 8$ & $25 \cdot 3$ & $25 \cdot 3$ & $28 \cdot 3$ & $28 \cdot 3$ & $28 \cdot 6$ & $28 \cdot 6$ & $29 \cdot 3$ \\
\hline \multirow[t]{20}{*}{ (b) } & $0-40$ & 6087.4 & $979 \cdot 4$ & $741 \cdot 6$ & $741 \cdot 6$ & 574.5 & $574 \cdot 5$ & $556 \cdot 1$ & $368 \cdot 9$ & $322 \cdot 7$ \\
\hline & $40-60$ & 351.6 & $269 \cdot 6$ & 443.6 & $443 \cdot 6$ & $589 \cdot 4$ & $46 \cdot 4$ & $41 \cdot 2$ & $41 \cdot 2$ & $83 \cdot 3$ \\
\hline & $60-90$ & $475 \cdot 7$ & $364 \cdot 7$ & $374 \cdot 2$ & $374 \cdot 2$ & $377 \cdot 7$ & 29.7 & 38.9 & 38.9 & $40 \cdot 6$ \\
\hline & $90-120$ & 420.0 & $322 \cdot 0$ & $328 \cdot 4$ & $328 \cdot 4$ & $330 \cdot 5$ & $26 \cdot 0$ & $28 \cdot 5$ & $28 \cdot 5$ & $28 \cdot 9$ \\
\hline & $120-150$ & 370.9 & $284 \cdot 3$ & 290.0 & $290 \cdot 0$ & $291 \cdot 8$ & $22 \cdot 9$ & $24 \cdot 4$ & 24.4 & $24 \cdot 7$ \\
\hline & $150-180$ & $327 \cdot 4$ & $251 \cdot 1$ & 256.0 & 256.0 & $257 \cdot 6$ & $20 \cdot 3$ & $21 \cdot 5$ & $21 \cdot 5$ & $21 \cdot 7$ \\
\hline & $180-210$ & $289 \cdot 1$ & $221 \cdot 7$ & $226 \cdot 1$ & $226 \cdot 1$ & $227 \cdot 5$ & $17 \cdot 9$ & $19 \cdot 0$ & $19 \cdot 0$ & $19 \cdot 2$ \\
\hline & $210-240$ & $255 \cdot 3$ & 195.7 & 199.6 & $199 \cdot 6$ & 200.9 & $15 \cdot 8$ & $16 \cdot 8$ & $16 \cdot 8$ & $17 \cdot 0$ \\
\hline & $240-270$ & $225 \cdot 4$ & $172 \cdot 8$ & $176 \cdot 2$ & $176 \cdot 2$ & $177 \cdot 4$ & 13.9 & $14 \cdot 8$ & $14 \cdot 8$ & $14 \cdot 9$ \\
\hline & $270-300$ & $199 \cdot 0$ & 152.6 & $155 \cdot 6$ & $155 \cdot 6$ & $156 \cdot 6$ & $12 \cdot 3$ & $13 \cdot 1$ & $13 \cdot 1$ & $13 \cdot 2$ \\
\hline & $300-330$ & $175 \cdot 7$ & $134 \cdot 7$ & $137 \cdot 4$ & 137.4 & $138 \cdot 3$ & $10 \cdot 9$ & $11 \cdot 5$ & $11 \cdot 5$ & $11 \cdot 6$ \\
\hline & $330-360$ & $155 \cdot 2$ & $119 \cdot 0$ & $121 \cdot 3$ & $121 \cdot 3$ & $122 \cdot 1$ & 9.6 & $10 \cdot 2$ & $10 \cdot 2$ & $10 \cdot 3$ \\
\hline & $360-390$ & 137.0 & $105 \cdot 1$ & $107 \cdot 1$ & $107 \cdot 1$ & $107 \cdot 8$ & $8 \cdot 5$ & $9 \cdot 0$ & $9 \cdot 0$ & $9 \cdot 1$ \\
\hline & $390-420$ & $121 \cdot 0$ & $92 \cdot 8$ & $94 \cdot 6$ & $94 \cdot 6$ & $95 \cdot 2$ & $7 \cdot 5$ & $7 \cdot 9$ & $7 \cdot 9$ & $8 \cdot 0$ \\
\hline & $420-450$ & $106 \cdot 8$ & 81.9 & $83 \cdot 5$ & $83 \cdot 5$ & $84 \cdot 0$ & $6 \cdot 6$ & $7 \cdot 0$ & $7 \cdot 0$ & $7 \cdot 1$ \\
\hline & $450-480$ & $94 \cdot 3$ & $72 \cdot 3$ & $73 \cdot 7$ & $73 \cdot 7$ & $74 \cdot 2$ & $5 \cdot 8$ & $6 \cdot 2$ & $6 \cdot 2$ & $6 \cdot 3$ \\
\hline & $480-510$ & $83 \cdot 3$ & $63 \cdot 9$ & $65 \cdot 1$ & $65 \cdot 1$ & $65 \cdot 5$ & $5 \cdot 2$ & $5 \cdot 5$ & $5 \cdot 5$ & $5 \cdot 6$ \\
\hline & $510-540$ & $73 \cdot 5$ & $56 \cdot 4$ & $57 \cdot 5$ & $57 \cdot 5$ & $57 \cdot 9$ & $4 \cdot 6$ & $4 \cdot 8$ & $4 \cdot 8$ & $4 \cdot 9$ \\
\hline & $540-570$ & $64 \cdot 9$ & $49 \cdot 8$ & $50 \cdot 8$ & $50 \cdot 8$ & $51 \cdot 1$ & $4 \cdot 0$ & $4 \cdot 3$ & $4 \cdot 3$ & $4 \cdot 3$ \\
\hline & $570-600$ & $57 \cdot 3$ & $44 \cdot 0$ & $44 \cdot 8$ & $44 \cdot 8$ & $45 \cdot 1$ & 3.5 & 3.8 & $3 \cdot 8$ & 3.8 \\
\hline
\end{tabular}

* Arrows indicate the mean numbers of follicles leaving (e.g. $\mathrm{I} \rightarrow$ ) the group by growth and death (or ovulation from Group $V$ in post-pubertal intact females) and entering (e.g. $\rightarrow$ II) the group by growth. 
21 days; the follicles accumulated in these stages, together with newly recruited follicles from the pool, are then slowly reduced throughout remaining life (Faddy et al., 1976). An excess of medium-sized follicles is thus always available for growth into later stages in all but the oldest mice (Table 2, Textfig. 5), allowing the species-specific ovulation rate to be maintained and providing the follicular system with a degree of flexibility. Oscillations in the numbers of medium and large follicles subside after 100 days, and by 350 days follicle turnover becomes sluggish, perhaps because few remain.

Hypophysectomy during early maturity has little apparent influence on the initiation of growth or on the incidence of death of follicles from the pool, the rates for both parameters being only slightly reduced compared to those in intact mature females (Table 2, Text-fig. 5). For example, the ovaries of a normal female aged 60 days contain 3917 primordial follicles; for a female hypophysectomized at 40 days of age, the corresponding number at 60 days is 4065 (from Table 2). However, as the post-operative interval increases the cumulative effects of slightly reduced growth and death rates, taken in conjunction with the resultant larger pool size at any age, become increasingly apparent. At 510 days of age, the number of primordial follicles in intact female mice is about 260 and the corresponding figure for a female hypophysectomized at 40 days and killed 470 days later is 630 .

In contrast, the effect of hypophysectomy on large follicles is clear, for within 20 days after operation they are severely reduced in number. In the absence of large follicles slightly fewer follicles leave the pool per unit time as described above, and the turnover of medium-sized follicles increases (Text-fig. 5). Follicles with two layers of granulosa cells (Group III) seem particularly vulnerable to the effects of hypophysectomy. The rate of growth into this category increases, which might indicate that large follicles exert suppressive effects on their growth in intact females, but in the absence of gonadotrophins very few are able to continue growth transition into the three-layered stage and the majority die as indicated by the increased death rate (Table 2, Text-fig. 5). A small number of follicles which survive to the three-layered stage can continue to grow spontaneously to the preantral or, occasionally, to a very early antral stage.

\section{Resumption of follicular growth in hypophysectomized rats}

Hypophysectomized rats are being used to study the resumption of follicular growth, especially in relation to the effects of gonadotrophins and steroids. Follicular changes were followed by simple morphometric methods: the number of follicles or the total of follicle profiles per unit of sectioned ovary were counted to obtain frequency distributions of the sizes of follicle profiles and estimates of their numerical, area or volume densities in the sections (Text-fig. 6). Measurements on equatorial and tangential follicle profiles were made on projected images from randomly chosen independent sections. Profile diameters were measured directly and areas and densities were estimated by a point counting method. The volume density was estimated from the area density according to the Principle of Delesse (Weibel, 1973). By 21 days after hypophysectomy, large antral stages have disappeared and the area density of follicle profiles is reduced to approximately $20 \%$ of that found in intact cyclic rats. Follicles of diameter $<175 \mu \mathrm{m}$ were by far the most frequent, with numerical densities remaining similar to those found before hypophysectomy (Text-fig. 6). Follicles of diameter $<60 \mu \mathrm{m}$ were not measured. Developing follicles with diameters up to $400 \mu \mathrm{m}$ were rarely found after hypophysectomy, and the population consisted mainly of non-growing primordial follicles and those preantral stages which are either insensitive or weakly sensitive to gonadotrophin depletion. The total number of growing preantral follicles does not change markedly, although fewer of the large preantral stages are present. The remaining multilaminar follicles are not undergoing obvious atresia. These observations indicate either that normal growth transition between early follicle stages is not maintained or that initiation and migration between stages is continued, but that an increase in atresia afflicts the later preantral stages. The latter suggestion appears to be correct, because the presence of mitotic figures in granulosa cells in multilaminar follicles implies that growth is continued, although the rates of transition may be abnormal.

The hypophysectomized rat can also be used to study the effect of gonadotrophin injections on changes in follicle growth. Injections of FSH (Armour Standard), HCG (Primogonyl: Schering) or both were used to study the changing follicle profiles a few days after the injection. Daily injections of 

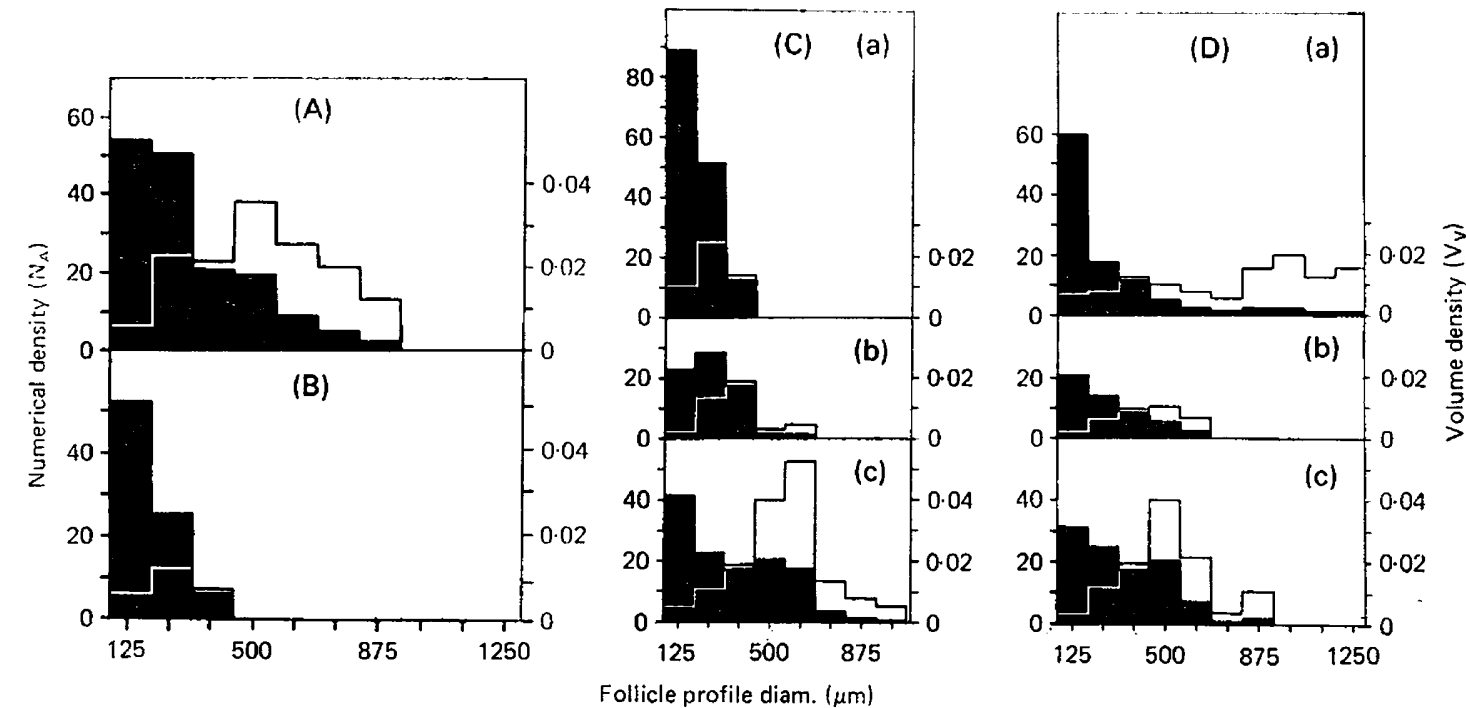

Text-fig. 6. Comparisons of distributions of follicles of different sizes in the ovaries of mature CFHB rats. Frequency distributions of the numerical density (solid columns) and volume density (open columns) of the follicles are shown. The numerical density estimates the no. of follicle profiles $/ 10^{8} \mu \mathrm{m}^{2}$ of ovarian section and the volume density emphasizes the three-dimensional contribution to (i.e. fraction of) the total ovarian volume. (A) Intact cyclic rats $(\mathrm{N}=5)$ at 6 weeks of age and various stages. (B) Rats $(\mathrm{N}=5)$ hypophysectomized 21 days earlier at 6 weeks of age and receiving daily saline injections for $96 \mathrm{~h}$. (C) Rats hypophysectomized 21 days earlier and receiving daily FSH injections (0.4 mg Armour Standard s.c. in saline; 9.64 i.u.). The animals were killed at (a) $24 \mathrm{~h}$ (one injection), (b) $48 \mathrm{~h}$ (two injections) or (c) $96 \mathrm{~h}$ (four injections) after the first injection. For (a) and (b) $\mathrm{N}=3$; for (c) $\mathrm{N}=6$. (D) Rats hypophysectomized 21 days earlier were (a) given a single injection of $0.4 \mathrm{mg}$ FSH (Armour) $+10 \mathrm{i} . \mathrm{u}$. HCG (Primogonyl: Schering) and killed $24 \mathrm{~h}$ later; (b) given $0.4 \mathrm{mg}$ FSH followed after $24 \mathrm{~h}$ by $0.4 \mathrm{mg} \mathrm{FSH}+10$ i.u. HCG and killed $24 \mathrm{~h}$ later; and (c) given 3 daily injections of $0.4 \mathrm{mg} \mathrm{FSH}, 0.4 \mathrm{mg}$ FSH +10 i.u. HCG $24 \mathrm{~h}$ later, and then killed after $24 \mathrm{~h}$. For (a) and (b) $\mathrm{N}=3$, for (c) $\mathrm{N}=5$. (Unpublished results of $\mathrm{R}$. E. Gore-Langton.)

$0.4 \mathrm{mg}$ FSH induced a proportionate increase in the first $24 \mathrm{~h}$ in the numbers and numerical densities of profiles in the classes of follicles with mean diameters of 125, 250 and $375 \mu \mathrm{m}$ (Text-fig.6). Over the next $24 \mathrm{~h}$, a slight upward shift occurred in the size distribution of follicles, apparently at the expense the smaller size classes. During the next $48 \mathrm{~h}$, substantial growth was noted with the formation of many medium and large follicles, some of ovulatory dimensions. The decreased numerical densities of the smaller classes after $48 \mathrm{~h}$ could be related to the expansion of large follicles and the consequent exaggeration of sectional areas. These changes in the numerical densities of the different profiles imply an increased transition of growing follicles. The increased rate of transition is probably the result of reduced follicular atresia and enhanced proliferation, but might also include a greater initiation of growth in primordial follicles. The suggestion of reduced atresia would support the prediction that FSH salvages growing follicles which would otherwise die (Faddy et al., 1976), yet would be contrary to the observed effects of FSH on rat ovaries in vitro (Pavic, 1963) and in hypophysectomized rats (Harman, Louvet \& Rosse, 1975). It would appear from these latter studies that while FSH stimulates follicular growth, the proportion of atretic follicles is increased.

The growth of all classes of follicles in hypophysectomized rats could have been influenced by changes in the amount of circulating steroids in response to the injection of gonadotrophins. However, the injections of FSH (0.4 mg Armour Standard daily for 4 days) had not significantly increased the serum levels of several steroids above the basal levels found in control hypophysectomized animals (Table 3); this lack of a steroidogenic response to FSH is in contrast to other studies using immature rats and a short period between hypophysectomy and hormone treatment (Nuti, McShan \& Meyer, 1974; Grimek, Nuti, Nuti \& McShan, 1976). FSH thus stimulated the growth of follicles in the 
absence of an increase in steroidogenesis. Four daily injections of 2 i.u. HCG stimulated steroidogenesis (Table 3), indicating that hypophysectomy had not completely destroyed the steroid-synthesising capacity of the ovary. Oestradiol-17 $\beta$ was found in high amounts, implying that follicles still retained a distinct capacity to synthesize this steroid 21 days after hypophysectomy. Progesterone secretion rose only slightly, perhaps because the persistent corpora lutea in the ovaries underwent functional regression in the post-operative period. The most marked effect of HCG was to stimulate production of high levels of androgens, although these may be partly of adrenal origin.

Table 3. Steroids (mean \pm S.E.M.) in the serum of intact and hypophysectomized rats treated in various ways (unpublished results of S. T. H. Chan and R. E. Gore-Langton)

\begin{tabular}{|c|c|c|c|c|c|c|}
\hline \multirow[b]{2}{*}{ Animals and treatment $\dagger$} & \multirow{2}{*}{$\begin{array}{l}\text { No. of } \\
\text { animals }\end{array}$} & \multicolumn{5}{|c|}{ Serum conc. $(\mathrm{pg} / \mathrm{ml})$ of steroids* } \\
\hline & & Oestradiol-17 $\beta$ & Oestrone & 4-Androstenedione & Testosterone & Progesterone \\
\hline $\begin{array}{l}\text { Intact, no further } \\
\text { treatment }\end{array}$ & 5 & $171 \pm 31$ & $144 \pm 50$ & $464 \pm 137$ & $698 \pm 93$ & $22,030 \pm 6720$ \\
\hline $\begin{array}{l}\text { Hypophysectomized, } \\
0.5 \mathrm{ml} \text { saline daily for } \\
4 \text { days }\end{array}$ & 5 & $28 \pm 12$ & $59 \pm 9$ & $167 \pm 111$ & $87 \pm 15$ & $3420 \pm 230$ \\
\hline $\begin{array}{l}\text { Hypophysectomized, } \\
0.4 \mathrm{mg} \text { FSH daily for } \\
4 \text { days }\end{array}$ & 6 & $24 \pm 11$ & $66 \pm 26$ & $107 \pm 13$ & $128 \pm 23$ & $4240 \pm 1210$ \\
\hline $\begin{array}{l}\text { Hypophysectomized, } \\
2 \text { i.u. HCG daily for } \\
4 \text { days }\end{array}$ & 5 & $176 \pm 46$ & $268 \pm 43$ & $2153 \pm 597$ & $2584 \pm 158$ & $6250 \pm 790$ \\
\hline
\end{tabular}

* Assayed by the methods described by Abraham (1974a).

$\dagger$ Injections were given s.c. and blood was collected from the dorsal aorta $96 \mathrm{~h}$ after the start of treatment.

FSH and LH could act synergistically to promote a greater growth of follicles. The combined effects of FSH and HCG are therefore being studied. Within $24 \mathrm{~h}$ of the injection of both gonadotrophins (0.4 mg FSH, 10 i.u. HCG), a few large Graafian follicles had formed (Text-fig. 6), unlike the effects of FSH or HCG alone. When the combined treatment with FSH and HCG was preceded by FSH alone for 24-72 h, the follicle profile $24 \mathrm{~h}$ later resembled that obtained with FSH given alone over a similar period. HCG may therefore enhance the growth responses of follicles progressing through antrum formation, but not of later stages.

\section{Normal and abnormal differentiation and steroidogenesis in follicles approaching ovulation}

\section{Timing of human ovulation}

The timing of ovulation must be closely controlled for studies on changes in steroidogenesis in preovulatory follicles. There is little chance of analysing preovulatory human follicles during the menstrual cycle by identifying the LH surge, because the time needed to assay LH is greater than the interval between the surge and ovulation. It is also difficult to organize operations within a few minutes of obtaining the results of an assay. Most observations on human preovulatory follicles during the natural cycle have been made by chance or by hopefully timing operations in mid-cycle.

We have therefore induced ovulation in women by injection of HCG at different endocrinological situations (Edwards \& Steptoe, 1975). Some patients were given HCG just before the surge of LH was expected during the middle part of the natural cycle; this method resembles natural ovulation very closely since follicular growth would occur under the control of endogenous hormones. The second method was to use human menopausal gonadotrophin (HMG) to stimulate follicular growth and then invoke ovulation with HCG. Thirdly, clomiphene was given to stimulate follicular growth and HCG to induce ovulation. Laparoscopy was used to examine and assess the ovaries at various times 
after the injection of HCG. Oocytes and granulosa cells were aspirated from many follicles and were also used to determine the stage of follicular growth by analysis of nuclear material and meiotic chromosomes in oocytes or the structure and secretory nature of the granulosa cells.

Our results (Table 4) show that ovulation in women begins approximately $37 \mathrm{~h}$ after the injection of HCG (Edwards \& Steptoe, 1975). It may occur at a similar interval after the initial rise of LH during mid-cycle (Ferin, Thomas \& Johansson, 1973). Some follicles were actually observed to rupture at approximately $37 \mathrm{~h}$ after $\mathrm{HCG}$, the disruption of the stigma being seen during laparoscopy. Fresh $\mathbf{C L}$ were noticed in several patients. The best time to study human preovulatory follicles is therefore approximately 32-33 h after the injection of HCG, at a time when the follicular fluid, granulosa cells and oocytes can be easily aspirated. Non-ovulatory and perhaps atretic follicles will also be present in the ovary at this time, permitting a comparison between the patterns of metabolism in these and the preovulatory follicles.

Table 4. Timing of human ovulation after HCG treatment (modified from Edwards \& Steptoe, 1975)

\begin{tabular}{ccc}
\hline Time after HCG (h) & No. of patients & No. with fresh CL \\
\hline $29-31$ & 59 & 1 \\
$32-35$ & 58 & $2 ?$ \\
$35-37$ & 5 & 1 \\
$37-38 \frac{1}{2}$ & 7 & 3 \\
$40-44^{*}$ & 9 & 6 \\
\hline
\end{tabular}

* Including some data from Dr A. Lopata.

\section{Follicular steroids in human preovulatory follicles}

The concentrations of various steroids have been determined in fluids aspirated from human follicles $32 \mathrm{~h}$ after an injection of HCG (Fowler, Chan, Edwards, Steptoe \& Walters, 1977). Most studies were carried out on patients given 5000 i.u. HCG just before the surge of $\mathrm{LH}$ was expected in mid-cycle. The endocrinological situation in the ovary would resemble that occurring during the natural cycle, except for differences such as those arising through the longer half-life of HCG compared with that of LH. The follicular and luteal phases of at least one earlier cycle had been assessed in each patient by daily assays of oestrogens, pregnanediol and $\mathrm{LH}$ on $24 \mathrm{~h}$ collections of urine. Similar analyses were carried out on urine samples taken during the treatment cycle, the gonadotrophin being given when the levels of urinary hormones indicated that the surge of LH was imminent (Text-fig. 7). Laparoscopy was performed 32-33 h after HCG injection and the size and morphology of follicles in the ovary was assessed and recorded. Each Graafian follicle was aspirated individually. Oocytes were found in many aspirates, and the follicle was classified as preovulatory if its oocyte possessed chromosomes in meiosis-I or was fertilized within a few hours, and non-ovulatory if the oocyte was vesicular. Other aspects of the aspirate were also used to classify the follicles. Large numbers of granulosa cells, including those surrounding the oocyte (Pl. 1, Fig. 2), and the presence of a viscous fluid in addition to normal follicular fluid indicated that the follicle was preovulatory. In nonovulatory follicles, few granulosa cells were recovered, the oocyte was surrounded by corona radiata and few cumulus cells, and the fluid contained none of the viscous material (Edwards \& Steptoe, 1975).

The concentrations of steroids were measured in the fluids with the antisera and radioimmunoassays extensively described by Abraham (1974a). There was a wide range of steroid concentrations in the follicular fluids (Table 5) and a large variation in the levels of steroid hormones in different follicles from the same patient. Inspection of the results suggested that follicles tended to fall into two groups. Some contained large amounts of progesterone, $17 \alpha$-hydroxyprogesterone and oestradiol-17 $\beta$ and low levels of androstenedione, $17 \alpha$-hydroxypregnenolone, dehydroepiandrosterone and testosterone, whereas the others contained low concentrations of progesterone and oestradiol-17 $\beta$ and relatively high amounts of the other steroids. Cluster analyses were therefore carried out on the 
(a)
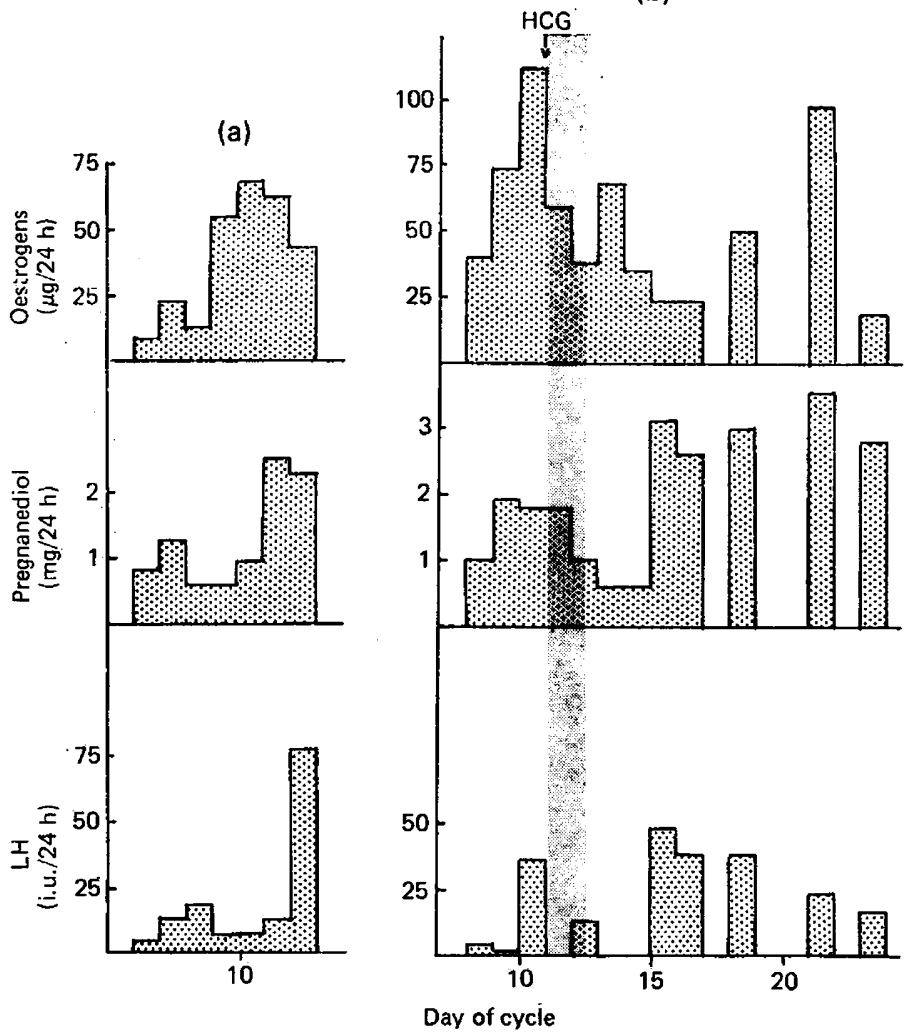

Text-fig. 7. Comparison of the hormone levels in women during (a) a natural cycle and (b) after an injection of HCG at mid-cycle to induce ovulation. (From Edwards \& Steptoe, 1974.)

data using the method described by Ward (1963). In a cluster analysis, all the available data on steroid levels in different follicles are compared, and follicles of close similarity are grouped in a manner which minimizes their within-group variance. Small amounts of fluid only were available for assays from some follicles, and the cluster analyses were therefore performed in two groups. First, data on 4 steroids (progesterone, pregnenolone, 17 $\alpha$-hydroxypregnenolone and dehydroepiandrosterone) were analysed since thesesteroids were measured in almost all follicles. A second analysis was carried out using assays of 8 steroids, all of which had been analysed in 9 follicles.

Table 5. Ranges of concentrations of steroids in fluids of human follicles near the time of ovulation after an injection of HCG in mid-cycle (data from Fowler et al., 1977)

\begin{tabular}{|c|c|c|}
\hline Steroid & $\begin{array}{l}\text { No. of } \\
\text { follicles }\end{array}$ & Range (ng/ml) \\
\hline Progesterone & 17 & $1-18,000$ \\
\hline $17 \alpha$-Hydroxyprogesterone & 11 & $27-1800$ \\
\hline Oestradiol-17 $\beta$ & 11 & $9-3600$ \\
\hline Oestrone & 11 & $2-122$ \\
\hline Androstenedione & 11 & $3-2160$ \\
\hline $17 \alpha-H y d r o x y p r e g n e n o l o n e$ & 17 & $3-450$ \\
\hline Dehydroepiandrosterone & 15 & $1-380$ \\
\hline Testosterone & 11 & $1-94$ \\
\hline Pregnenolone & 15 & $48 \rightarrow 1000$ \\
\hline
\end{tabular}


Table 6. Mean steroid concentrations (log conc. $\mathrm{ng} / \mathrm{ml}$ ) in preovulatory and non-ovulatory follicles (see text) as ovulation approaches in women given HCG in mid-cycle (data from Fowler et al., 1977)

\begin{tabular}{|c|c|c|}
\hline & Preovulatory & Non-ovulatory \\
\hline Progesterone & $8 \cdot 5$ & $3 \cdot 7 * *$ \\
\hline 17 $\alpha$-Hydroxyprogesterone & 6.8 & $4 \cdot 2^{*}$ \\
\hline Oestradiol-17 $\beta$ & $7 \cdot 1$ & $3 \cdot 6 * *$ \\
\hline Pregnenolone & $6 \cdot 3$ & $4.9 * *$ \\
\hline Oestrone & $3 \cdot 4$ & $1 \cdot 4$ \\
\hline Androstenedione & $3 \cdot 3$ & $7 \cdot 2^{* *}$ \\
\hline 17 $\alpha$-Hydroxypregnenolone & $1 \cdot 7$ & $4 \cdot 7^{* *}$ \\
\hline Dehydroepiandrosterone & 0.9 & $4.9 * *$ \\
\hline Testosterone & 1.9 & $3 \cdot 8 * *$ \\
\hline
\end{tabular}

$* P<0.02 ; * * P<0.01$ by a Randomization Test.

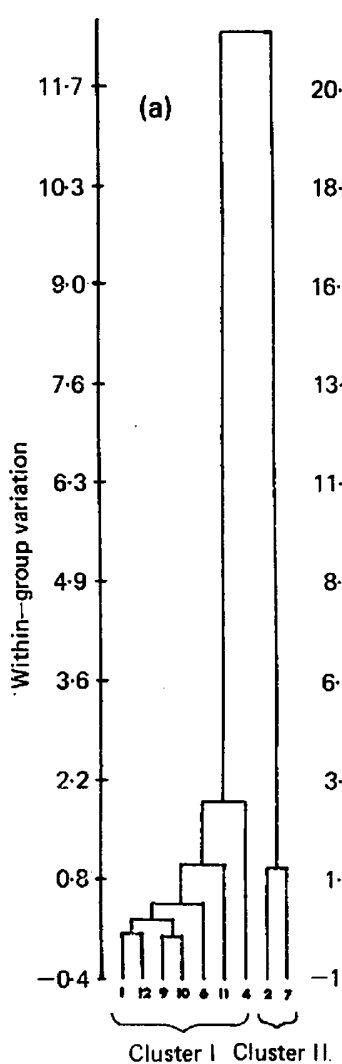

Cluster I Cluster II.

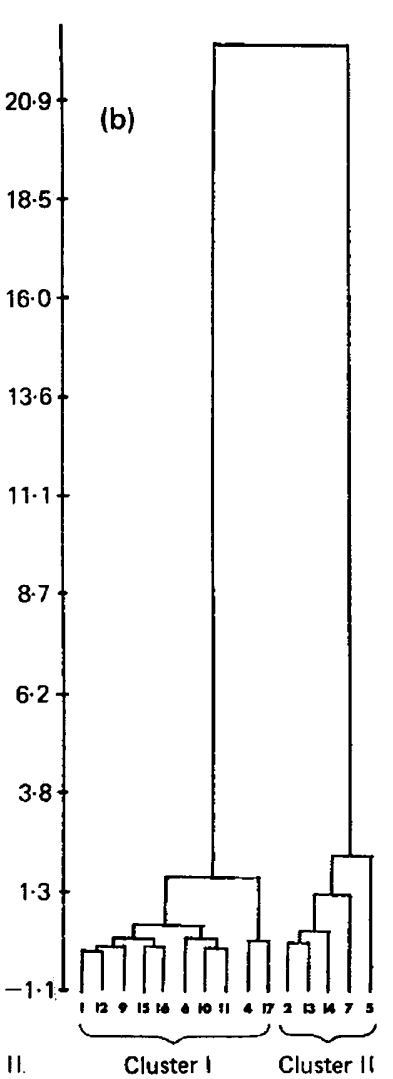

Follicle number

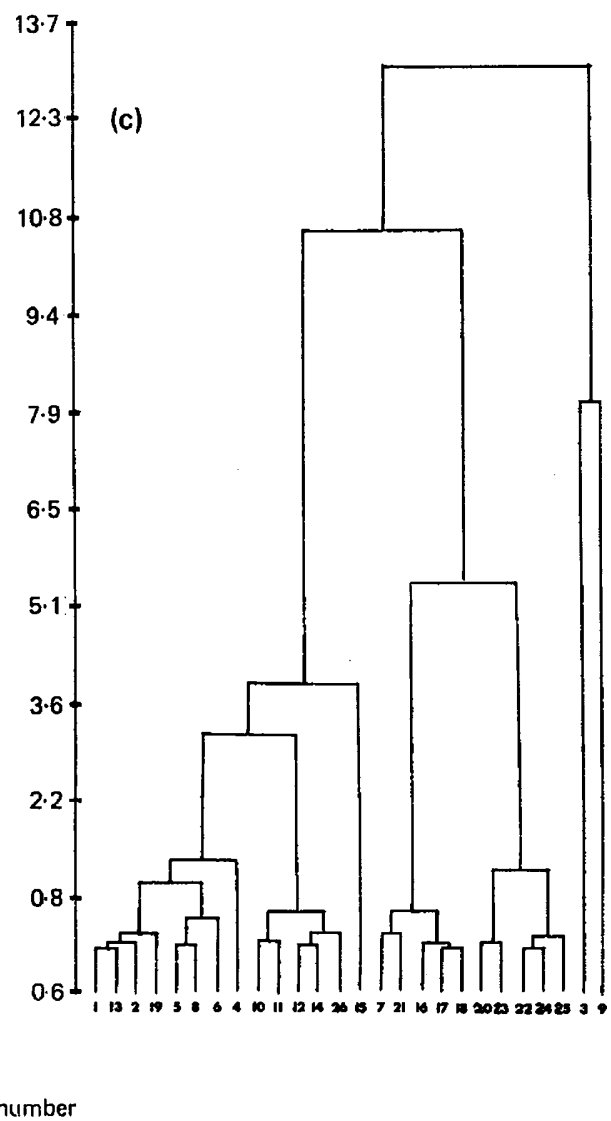

Text-fig. 8. Dendograms showing cluster analyses of steroids in human follicular fluid aspirated $32 \mathrm{~h}$ after HCG injection alone in mid-cycle (a, b) and $32 \mathrm{~h}$ after the HCG injection following HMG or clomiphene treatment (c). The steroids analysed were: (a) progesterone, 17a-hydroxyprogesterone, pregnenolone, 17 $\alpha$-hydroxypregnenolone, androstenedione, testosterone, oestradiol-17 $\beta$, oestrone, (b) progesterone, pregnenolone, 17 $\alpha$-hydroxypregnenolone, dehydroepiandrosterone; (c) progesterone, 17 $\alpha$-hydroxyprogesterone, 17 $\alpha$-hydroxypregnenolone, androstenedione, testosterone, oestradiol-17 $\beta$, oestrone. (Dendograms (a) and (b) from Fowler et al., 1977.) 
The results of these analyses (Text-fig. 8) indicated clearly that each follicle could be placed into one of the two clusters. Combining the two clusters into a single group caused a very large increase in the within-group variance, revealing the existence of two distinct clusters of follicles. Clustering on the basis of steroid concentrations was entirely consistent with the grouping of follicles as either preovulatory (Cluster I) or non-ovulatory (Cluster II) at the time of laparoscopy. The mean concentrations of steroids in the two groups of follicles differed significantly (Table 6).

One follicle was exceptional. The oocyte had undergone maturation and was fertilized in vitro, but the follicle had not luteinized as judged by observations at laparoscopy. Steroid analyses also showed that the follicle was non-ovulatory. Oocyte maturation and luteinization can occur independently under some conditions, and maturation of the oocyte without luteinization has also been observed in old rats and in atretic follicles of animals, as discussed later. This human follicle was evidently not atretic because it contained levels of steroids similar to those of non-ovulatory follicles: Oocyte maturation may therefore be stimulated more easily than luteinization in human follicles.

Similar studies have been carried out on follicles of patients given HMG and HCG and included one patient given clomiphene followed by HCG (Edwards \& Steptoe, 1975). Follicular growth would have been stimulated by the injections of HMG which were given on alternate days from Day 3 until Day 9 and ovulation induced by the HCG given on Day 11.

Large numbers of Graafian follicles are present in these patients when laparoscopy is performed $32 \mathrm{~h}$ after the injection of HCG. Analysis of the steroids in follicular fluids revealed that the relationship between steroidogenesis and the development of follicles was more complex than when HCG was given during the natural cycle. The dendograms of the cluster analysis (Text-fig. 8) showed that the follicles did not fall into two groups; the within-group variance increased in a fairly regular manner as clustering proceeded. Most of the large preovulatory follicles contained high concentrations of progesterone, $17 \alpha$-hydroxyprogesterone and oestradiol-17 $\beta$, but other follicles appeared to be intermediate between non-ovulatory and preovulatory follicles. Large numbers of follicles were stimulated and at laparoscopy appeared to be in different stages of development, hence the complex steroidogenic pattern.

These observations show that conclusions about the nature of the luteal phase following the use of HMG and HCG must be made cautiously. Since follicles in various stages of development are present after the injection of HCG, some of them may continue to develop after the preovulatory follicles have ruptured. Fluctuations in plasma or urinary hormones during the luteal stage may therefore refiect a series of subsequent ovulations and luteinizations rather than the activity of those follicles which ruptured $37 \mathrm{~h}$ after the injection of HCG. The relatively long life of HCG compared with that of LH might also encourage the continued luteinization of some follicles.

\section{Fluctuations in ovarian $\Delta^{5}-3 \beta$-hydroxysteroid dehydrogenase and $\Delta^{5}$-isomerase activity of rats during the oestrous cycle}

There have been many studies on the nature of the control of ovarian steroidogenesis by gonadotrophins. Changes in the activity of certain enzymes involved in steroidogenesis may be one cause of the fluctuation in hormone secretion during the oestrous or menstrual cycle, as shown by the following study.

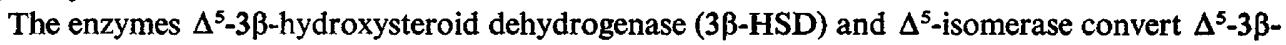
hydroxysteroids to $\Delta^{4}$ ketosteroids in mammalian tissue (Samuels, Helmreich, Lasater \& Reich, 1951). The histochemical technique of Wattenberg (1958) for the visualization of $3 \beta-H S D$ activity has been used to demonstrate this enzyme in a number of steroidogenic tissues in mammals. In the rat ovary, 3 $\beta$-HSD activity is seen in the granulosa cells of large follicles and in the theca interna (Pupkin,

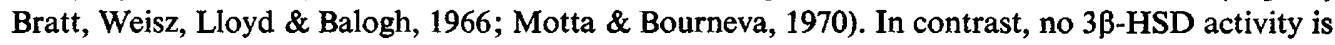
seen in sheep granulosa cells at any stage of the cycle (Hay \& Moor, 1975) and the ultrastructure of granulosa cells of the rhesus monkey provides no evidence to suggest that these cells are involved in steroid hormone production (Amin, Richart \& Brinson, 1976).

With an in-vitro technique we have measured $3 \beta-H S D$ activity in rat ovarian tissue throughout the oestrous cycle and related these changes to fluctuating levels of steroid hormones in the peripheral circulation (Readhead \& Abraham, 1977). 


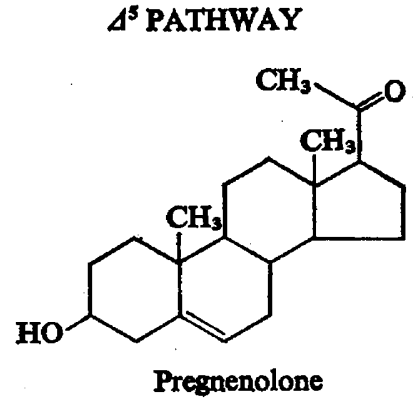

(2)<smiles>CC(=O)O[14C](=O)[O-]</smiles>

(3)<smiles>CC12CCC3C(CC=C4CC(O)CCC43C)C1CCC2=O</smiles>

Dehydroepiandrosterone

(4)

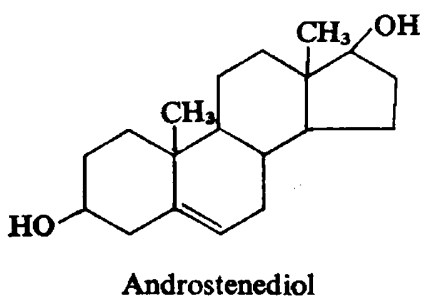

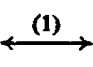<smiles>CC(=O)[C@H]1CCC2C3CCC4=CC(=O)CCC4(C)C3CCC21C</smiles>

Progesterone

(2)

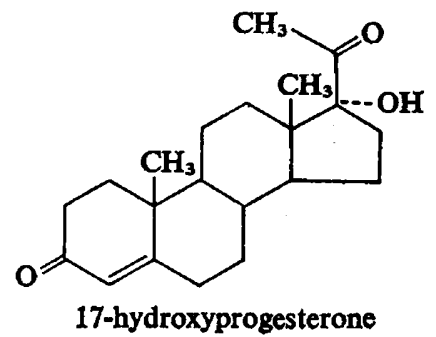<smiles>[131IH]</smiles>

$\stackrel{(1)}{\longleftrightarrow}$<smiles></smiles>

Androstenedione (4)<smiles>[Te]</smiles><smiles>CC12CCC(=O)C=C1CCC1C2CCC2(C)C(O)CCC12</smiles>

Testosterone

Text-fig. 9. Pathways of steroid metabolism in the rat ovary. $1, \Delta^{5}-3 \beta$-ol-dehydrogenase $\Delta^{5}-\Delta^{4}$-isomerase; 2, $\mathrm{C}_{21}$ steroid 17-hydroxylase; 3, $\mathrm{C}_{17-20}$ desmolase;4,17ß-hydroxysteroid dehydrogenase. (From Readhead \& Abraham, 1977.) 
Table 7. Steroid concentrations $(\mathrm{pg} / \mathrm{ml})$ in the follicular fluids of women with the polycystic ovary syndrome (Stein-Leventhal syndrome) and in non-ovulatory and preovulatory follicles as ovulation approaches in women given $\mathrm{HCG}$ in mid-cycle

\begin{tabular}{|c|c|c|c|c|}
\hline Follicle type & Progesterone & $\begin{array}{l}17 \alpha-H y d r o x y- \\
\text { progesterone }\end{array}$ & Androstenedione & Oestradiol-17 $\beta$ \\
\hline Polycystic* & $70-130$ & $<23-130$ & $<28-1000$ & $<15-83$ \\
\hline Normal* & $90-3100$ & $23-850$ & $10-780$ & $40-2500$ \\
\hline Non-ovulatory $\dagger$ & 103 & 101 & 1438 & 53 \\
\hline Pre-ovulatoryt & 7019 & 1071 & 46 & 1520 \\
\hline
\end{tabular}

* Data from Short (1964) and Giorgi (1963).

$\uparrow$ Present data.

with steroids (Everett, 1964). The hall-mark of this condition is follicular development without ovulation, and this is attributed to a primary disturbance of the hypothalamic/pituitary regulation of gonadotrophin secretion. However, the consequences of this condition for ovarian function, follicle growth and steroidogenesis are not well understood.

The ovaries of persistent oestrous rats contain follicles of all sizes, but lack recently-formed CL (P1. 2, Fig. 3). The remarkable arrest in development and accumulation of small vesicular follicles found in polycystic human ovaries does not occur in persistent oestrous rats, or apparently in monocystic human ovaries. In rats, large Graafian follicles containing an oocyte with a germinal vesicle are characteristically present and are presumably the main source of the oestrogens responsible for the chronic stimulation of the reproductive tract. Follicle replacement could be regulated by the action of pituitary hormones on intra-ovarian factors. Circulating levels of LH and FSH in rats in persistent oestrus were compared with those in rats with a 4-day cycle on the morning of pro-oestrus, before the LH surge (Table 8). Levels of LH were similar in both groups, but the amount of FSH was significantly higher in the persistent oestrous rats, perhaps through differences in pituitary suppression by ovarian steroids. There is no apparent deficiency of gonadotrophins to support follicular growth in persistent-oestrous rats: peripheral concentrations of unconjugated oestrogens are variable in such rats, but do not exceed values attained during the oestrous cycle (Naftolin, Brown-Grant \& Corker, 1972; R. G. Gosden, unpublished).

Table 8. Circulating levels (mean \pm S.E.M.) of $\mathrm{LH}$ and FSH in young cyclic Sprague-Dawley rats on the morning of pro-oestrus and in ageing rats in persistent oestrus (R. G. Gosden, unpublished)

\begin{tabular}{lccc}
\hline \multicolumn{1}{c}{ Rats } & No. of animals & Plasma LH (ng/ml) & Plasma FSH (ng/ml) \\
\hline Young and cyclic & 14 & $38 \pm 3$ & $223 \pm 20^{*}$ \\
Old, in persistent oestrus & 13 & $40 \pm 4$ & $303 \pm 23^{*}$ \\
\hline
\end{tabular}

The hormone values are the NIAMDD-rat-LH-RP1 and NIAMDD-rat-FSH-RP1 equivalents.

* Significantly different $(P<0.02)$.

In our experience, the large follicles of rats in persistent oestrus induced spontaneously and by light have a reduced sensitivity to hormonal stimulation. Some ovulations occurred when these rats were exposed to large quantities of $\mathrm{LH}$, either provided exogenously or invoked by electrical stimulation of the brain, but the CL were smaller than in cyclic animals treated in the same way (R. G. Gosden, unpublished). Furthermore, quantities of LH sufficient to induce ovulation in cyclic animals reinitiated meiosis in some oocytes of persistent oestrous rats: the oocytes became surrounded by secretory cumulus cells, but ovulation and luteinization failed (P1. 2, Fig. 4). The cessation of follicle growth as a result of diminished sensitivity to gonadotrophins may mark the onset of degeneration of cystic follicles in rats. Cellular degeneration could be augmented by compression atrophy from accumulating follicular fluid. Another type of cyst containing only a simple membrane is frequently seen in these ovaries, and is probably a relic of a former follicle. Further growth of these cysts appears to be limited and they may regress when the follicle cells disappear. 
P'LATE: I
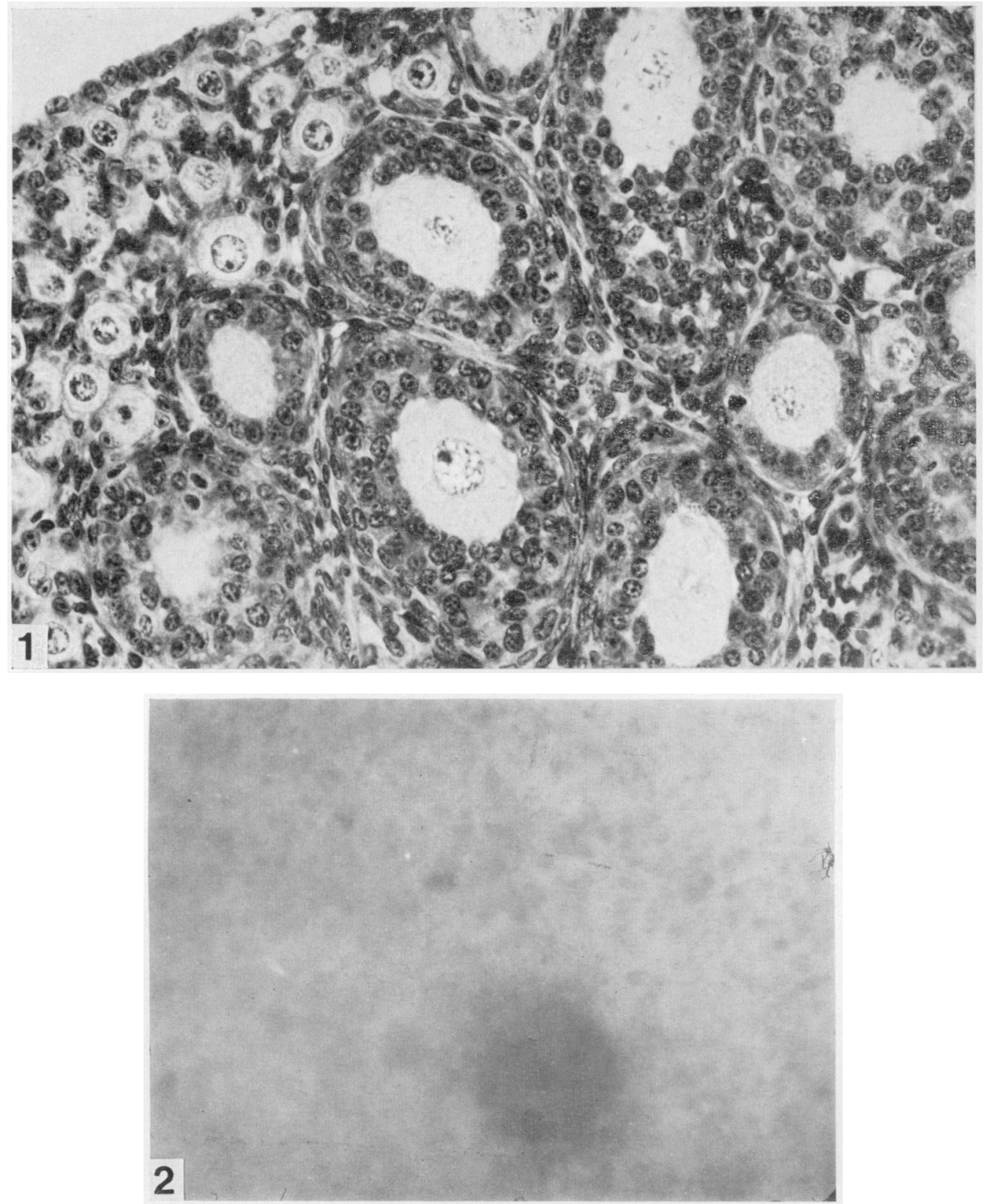

Fig. 1. Section of an ovary from a s-day-old female mouse showing the primordial follicles and growing follicles with one or two latyers of gramulosa cells. $\times 380$.

Fig. 2. A living preovulatory oocyte aspirated from a human Gratian follicle 32 h after an injection of $H C$; and photographed in culture. The depth of the preparation is shown by the diffuse appearance of the ooc to and its corona radiata, and by the masses of cumulus cells which extend to the edge of the illustration and beyond. Non-ovulatory oocytes possess small cumulus masses closely associated with the corona radiata. (R. G. Folwards \& P. C. Steptoe, unpublished.) 

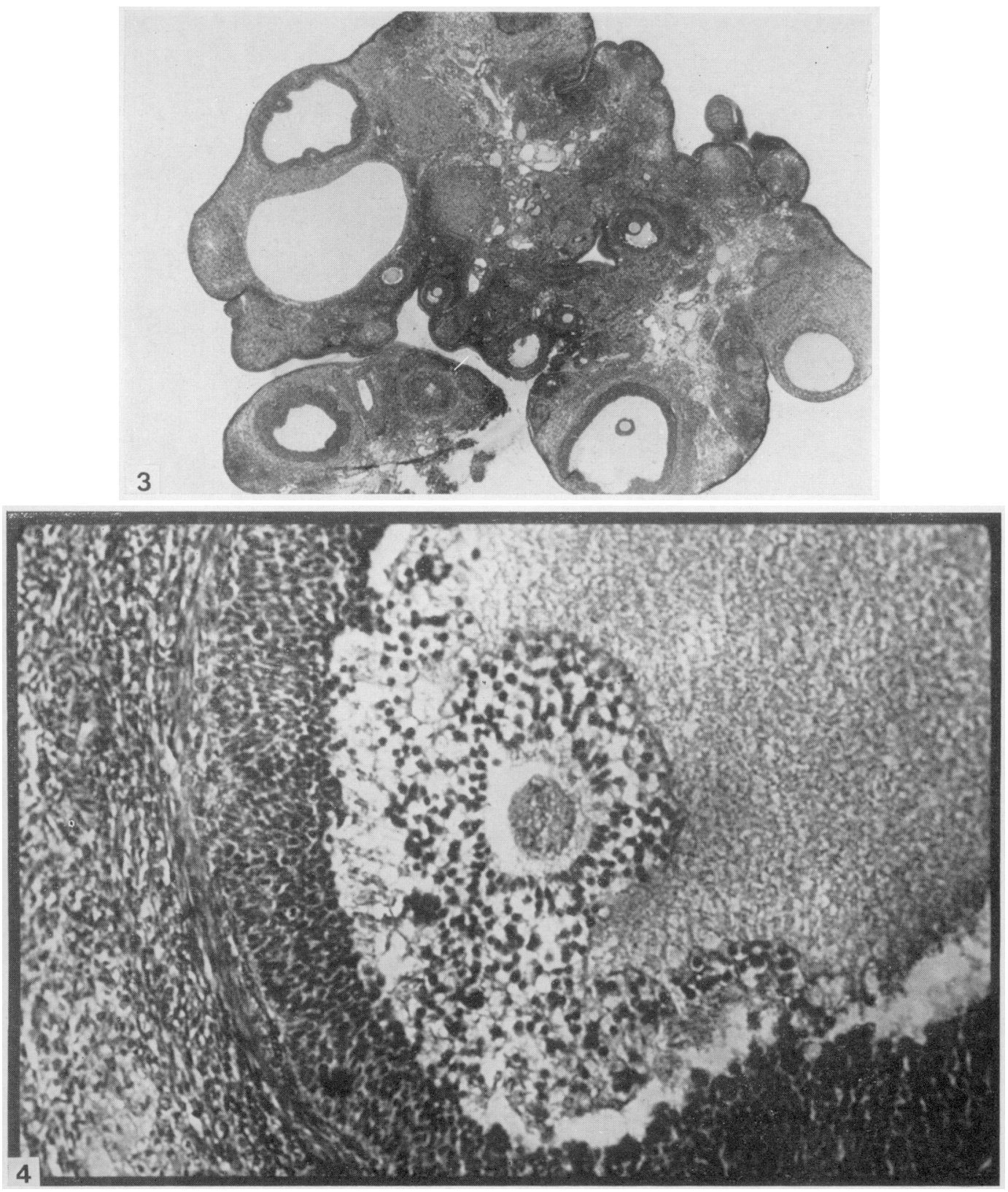

Fig. 3. Ovary of a 9-month-o!d rat which spontancously entered fersistent gestrus", show ing the large follicles and tic lach of $\mathrm{Cl}$.

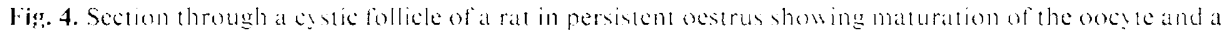
secretory cumblus but mo concomitam lutcinization. 


\section{Discussion}

\section{Factors in the initiation of follicular growth}

Although the mechanisms involved in the initiation of follicular growth are unknown, several principles appear to govern the loss of oocytes from the non-growing pool. In mice, the use of a semilogarithmic transformation of the data implied that a constant proportion of oocytes is lost per unit interval of time with increasing age (Jones \& Krohn, 1961a). For example, from the data on mice of strain A, the mean proportional reduction in oocytes from the total population over each 100-day interval by growth, ovulation and death is the same, irrespective of age (Table 9). The principle of a constant proportion of loss appears to hold true for all the strains investigated with each strain having a characteristic rate of reduction in numbers of oocytes. A similar conclusion was drawn for strain A from predictions from the model (see p. 241) during maturity (Faddy et al., 1976).

Table 9. Relationship between the total number of oocytes and the probability of oocyte loss in virgin A-strain mice (data from Jones \& Krohn, 1961a) and rats (data from Mandl \& Zuckerman, 1951)

\begin{tabular}{cccc}
\hline $\begin{array}{c}\text { Age } \\
\text { (days) }\end{array}$ & $\begin{array}{c}\text { Estimated total } \\
\text { oocyte population }\end{array}$ & $\begin{array}{c}\text { No. of oocytes lost } \\
\text { /100-day interval }\end{array}$ & $\begin{array}{c}\text { Proportion of oocytes lost } \\
\text { /100-day interval }\end{array}$ \\
\hline $\begin{array}{c}\text { Mice* } \\
00\end{array}$ & 8531 & & \\
100 & 4150 & 4381 & $0 \cdot 514$ \\
200 & 2018 & 2132 & $0 \cdot 514$ \\
300 & $981 \cdot 7$ & $1036 \cdot 3$ & $0 \cdot 514$ \\
400 & $477 \cdot 5$ & $504 \cdot 2$ & $0 \cdot 514$ \\
500 & $232 \cdot 3$ & $245 \cdot 2$ & $0 \cdot 514$ \\
\hline Rats & & & \\
100 & 4064 & & \\
200 & 2924 & 1140 & 0.281 \\
300 & 2410 & 514 & $0 \cdot 176$ \\
400 & 2099 & 311 & $0 \cdot 129$ \\
500 & 1888 & 211 & $0 \cdot 101$ \\
600 & 1734 & 154 & 0.082 \\
\hline
\end{tabular}

* Calculations were made from the regression equation: $\log y=3.481-0.00313(x-143 \cdot 704)$

where $y=$ number of oocytes and $x=$ age.

$\dagger$ Calculations were made from the regression equation: $\log y=4.561-0.476 \log x$

where $y=$ number of oocytes and $x=$ age.

Analysis of the numbers of follicles actually growing indicates that the fraction of growing: nongrowing oocytes in Bagg strain mice increased as the size of the pool decreased, either as a result of age or of treatment with dimethylbenzamine (Krarup, Pedersen \& Faber, 1969). A similar dependence on pool size of the proportion beginning to grow has been demonstrated by reducing the pool in neonatal mice by treatment with androgen (Peters, Byskov \& Faber, 1973). Such evidence implies that there is an increasing likelihood of a follicle leaving the pool by growth as the female ages. Observations from our fitted model support some of these conclusions. Calculations based on the model show that the ratio of developing : small follicles increases up to the age of 100 days, but thereafter remains constant despite the continued reduction in size of the non-growing component (unpublished observations).

When taken together, the indications of a constant proportion of follicle loss from all causes (A, CBA and RIII strains) and an increasing probability of growth initiation (Bagg strain) imply that the loss of oocytes by degeneration decreases with age as the pool is depleted. A decreasing fraction of atretic oocytes was reported with increasing age in strain A mice (Jones \& Krohn, 1961a), although not in other strains, and any generalizations would be inappropriate. Conclusions from our fitted model show that loss by death was very high between $\mathbf{0}$ and $\mathbf{3 0}$ days and much less in older females. 
These relationships in mice suggest that the pool of non-growing follicles might be considered as a resting population possessing a distribution of probabilities for utilization and specifically for growth initiation. These parameters may be strain-specific. Changes in the numbers of follicles in various stages of development according to age might reflect the effects of age, selective depletion of oocytes from the pool by growth or death and theaction of intra-or extra-ovarian factors. Such influences might display species variation, the particular relationship between growth initiation and pool size being coincidental rather than causal. For instance, the data of Mandl \& Zuckerman(1951) and Ingram (1953) on oocyte loss in rats showed that the relationship between the total number of oocytes and age is best represented linearly by a double logarithmic transformation, i.e. a function different from that used for mice. Use of this double logarithmic transformation implies that the proportion of oocytes lost from the total population per unit time interval decreases with increasing age (Table 9). If this relationship in the rat is valid, it contrasts with the constant proportionate loss found in mice, but more analyses are needed to confirm that such species differences do exist.

Asynchrony during meiotic prophase and the sequential formation of follicles in the fetal or neonatal ovary may provide a basis for understanding how a distribution of probabilities for the initiation of growth might arise. If oocytes in late-forming follicles have fewer chiasmata, and such follicles are conserved until the end of reproductive life, the implication is that these follicles have a lower intrinsic probability for the initiation of growth. The small follicles with the highest intrinsic probability of growth would thus be the first to be depleted from the pool by initiation, and the first oocytes ovulated would be those with the highest chiasma frequency. A progressive decline in chiasma frequency would occur as pool size was reduced. We have no idea at present of the biochemical causes leading to such postulated differences in the probability of follicular growth. One analytical approach would be to find out if other species show a distribution of chiasma frequency with age, as in the mouse, and the rat will be a suitable species to examine since meiotic prophase is better synchroized in oocytes in the fetal rat (Beaumont \& Mandl, 1962) than in the mouse. In several species, including man, the initiation of meiosis in oocytes takes place over a much longer time, perhaps as long as 2 or 3 months of fetal life, and more studies are needed on chiasma frequency in human oocytes to decide if the sequential utilization of oocytes occurs in the human ovary and is responsible for chromosome errors in human fetuses (Fowler \& Edwards, 1973). The number of follicles in the pool in human ovaries declines with age in a manner generally similar to that in mice (Block, 1952; Baker, 1972), but more studies are needed to establish that the details of follicular growth are similar in these species.

\section{The dynamics of follicle growth}

New techniques are needed to study the growth of follicles. The timing of follicle growth, for example, is imprecise in the absence of methods for selectively labelling them at particular stages of growth. The number of follicles passing through any stage at any specific age will be influenced by their transit time, and by growth and death rates in earlier stages of development.

A model such as the death/migration model described in the present work (p. 239) defines relationships existing between follicles at different stages of development from birth to senescence, and separates growth and death parameters for all follicle groups at any age. Static histological observations on numbers of follicles are transformed into a dynamic picture of the turnover of follicles in each developmental stage throughout life. All the parameters in such a model are interdependent; any alteration in one implies change in another. Each parameter can be confirmed or denied independently by different methods of analysis. Some conclusions drawn from the model agree with those obtained from methods such as tracer dilution (Pedersen, 1972), e.g. the large number of follicles leaving the pool during the first $\mathbf{3 0}$ days, and the lower rate of growth in follicles in groups 2 and 3 after 28 days. Other conclusions, e.g. the further decrease in the growth of some medium-sized follicles and the continuing low level of death in Group I after 30 days (Faddy et al., 1976), are not in accord.

The model has indicated a considerable regularity in follicular growth throughout life and the ovarian system will be even more regular if formal proof is obtained of a sequential formation and 
utilization of follicles. Interrelationships appeared to exist between the various groups of follicles, i.e. the numbers of medium-sized follicles subside as larger follicles reach a maximum, implying that there may be feedback effects from large follicles. Similar conclusions about the feedback effects of follicles have been reached by Peters et al., (1973), although they suggested that such a mechanism acted primarily by reducing the initiation of growth of follicles from the pool. Chalones may also exert feedback effects (Bullough, 1973; Clermont \& Mauger, 1976). Atresia appears to assume a new significance as a regulatory device, especially during immaturity. An explosive migration of follicles from the pool is prevented during this period by a high death rate operating against Group-I follicles. Furthermore, despite the elevated levels of gonadotrophin circulating in immature female mice (Dullaart, Kent \& Ryle, 1975), many follicles die during the transition from the 3- to 4-layered stage and the number available for growth to larger sizes is thereby controlled. During maturity, there is a 10-fold reduction in atresia of follicles in the pool and growth proceeds with negligible death to the 4layered stage, after which follicle survival is influenced by the degree of gonadotrophic stimulation. The stockpiling of follicles noted in Groups II and III clearly needs further analysis; some form of selection could occur since some of these follicles appear to grow more slowly than the others and might be defective.

Using this analytical approach we can predict the numbers of different types of follicles present in the ovaries of mice at different ages and, for the first time, attempt to estimate the numbers which move into and out of each developmental group and the numbers in each group which die per unit interval of time throughout the lifespan (Faddy et al.,1976). This approach offers the opportunity for detailed studies of the influence of various treatments on follicle growth, and hypophysectomy was used as an example in the present work. Analyses are needed on the effects of oral contraceptives, especially in relation to their suppression of the development of large follicles together with any consequential effects on the turnover of medium-sized follicles. Similar studies are also needed on follicle growth in rodents given androgens neonatally, which interferes with normal ovarian development, or in female mice carrying the gene $W^{v}$ which greatly reduces the size of the follicle pool (Mintz \& Russell, 1957). Few primordial follicles are present in XO women (Singh \& Carr, 1966), and the $W^{v}$ gene may provide an animal model for this clinical condition. We may be able to use the model predictively. The parameters of follicle growth and death are currently being analysed in three more strains of mice. Any strain differences will identify those stages of follicle growth and death most susceptible to genetic variation, and could indicate the underlying physiological controls. Strain differences in levels of gonadotrophins or steroids, for example, might influence specific stage(s) of follicle growth, and follicular activity could then prove to be predictable, based on parameters such as the number of follicles in the stem population and particular rates of utilization.

\section{Follicular growth after hypophysectomy}

The analysis of follicle growth and death in mice hypophysectomized after puberty illustrated the effects of gonadotrophin withdrawal on follicles of different sizes. A considerable depression was noted in the growth of large follicles, their numbers being severely reduced within 20 days. Few follicles persisted beyond the 2-layered stage (Group III), and these follicles appeared highly sensitive to hypophysectomy. However, the rate of migration into this group from Group II increased, implying again that large follicles may exert inhibitory feedback effects on certain of the earlier stages of growth. The rates of death and migration from Group I were reduced, but these effects were slight and became increasingly apparent only after longer intervals. They were most clearly illustrated by comparing hypophysectomized and intact females at advanced ages: by 510 days of age the ovaries contained 630 and 260 primordial follicles respectively. In an intact female, about 17 primordial follicles leave the pool over a $24-\mathrm{h}$ period by growth at the age of 60 days; in a female hypophysectomized at 40 days, 13 follicles begin to grow during the corresponding time interval. Failure to establish statistically significant differences between total numbers of follicles in intact and hypophysectomized rats (Ingram, 1953) may have been due to the relatively short time over which observa- 
tions were made. Initiation of follicular growth from the pool in mice is largely independent of any direct gonadotrophic stimulus or of any suppressive effects of antral follicles following post-pubertal hypophysectomy. Our observations on hypophysectomized rats agree with this conclusion, as judged from the numbers of growing follicles in early preantral stages. Similar studies are needed on females hypophysectomized at birth when rates of follicle death and migration are very high and presumably susceptible to slight changes in levels of hormones.

FSH is an adequate stimulus for the resumption of normal follicular growth in the hypophysectomized rat, even in the absence of increased steroidogenesis, for it enhances the numbers of all stages of growing follicles by increased migration and rescues the larger preantral stages from eventual atresia. Hypophysectomy does not prevent the follicle cells from acquiring sensitivity to FSH through the synthesis of receptors, although the continued preantral growth seen after hypophysectomy would indicate that these stages are not dependent on FSH. The enhanced growth of earlier preantral follicles after FSH stimulation could result from the influence of growth-promoting substances elaborated by large follicles. The production of steroids above basal levels is not essential for follicle growth. Nevertheless, an increase in the number of larger oestrogen-secreting follicles might be associated with the enhancement of FSH receptors in medium-sized growing follicles (Goldenberg, Vaitukaitis \& Ross, 1972; Goldenberg, Reiter \& Ross, 1973) and make them more sensitive to the growth stimulus; conversely, a reduction in the number of large follicles might lower the sensitivity of early follicles to the growth stimulus. Oestrogens also prevent the early follicular atresia caused by FSH (Harman et al., 1975) and may thus play a role in enhancing the sensitivity to FSH and possibly reducing atresia. In the intact animal, gonadotrophins may induce the release of steroids and so potentiate the growth stimulus and therefore regulate the balance between numbers of antral and smaller follicles.

HCG alone did not increase the numbers of growing follicles, although it did stimulate steroidogenesis. Oestrogens synthesized in response to HCG had evidently not influenced follicular growth despite their mitogenic effects. Nevertheless, HCG may augment the action of FSH on follicle growth through the production of oestrogen as described above, and also through the production of androgens, which may assist in the binding of gonadotrophins (Mizejewski, 1976). HCG was apparently less effective on the growth of preantral follicles after priming them with FSH, but this could have been due to methodological problems in distinguishing rapid follicular development in the presence of pre-existing large follicles. HCG also failed to promote the growth of antral follicles invoked by treatment with FSH, perhaps because binding sites for HCG appeared on granulosa cells and led to the initial stages of luteinization (Zeleznik, Midgley \& Reichert, 1974).

Our observations on follicular growth in hypophysectomized rats and mice have been discussed in relation to the possible inhibitory effects of large follicles, and to the stimulatory effects of oestrogen released from antral follicles. Clearly, there could be complicated interrelationships between follicles of different stages at different times. This situation would not be unusual, as it has been reported to exist in other types of tissue.

\section{Does the oocyte or granulosa cell control the development of the follicle?}

We have outlined evidence to show that the control of follicular growth is exerted at various stages throughout the formation, utilization and luteinization of the follicle. The oocyte or granulosa cell could control follicular development, assuming that the ovarian stroma is not involved, and we shall discuss briefly the relative importance of these two types of cell.

The role of the oocyte in determining the initiation of growth in follicles was stressed initially from measurements of oocyte and follicular diameters (Brambell, 1928), for enlargement of the oocyte is the first sign of growth of follicles in the pool followed by the proliferation of granulosa cells. But granulosa cells function as nurse cells, with many proteins being transmitted into the ooplasm across the nexuses between these cells and the oocyte membrane (Zamboni, 1974). Initial enlargement of the oocyte could reflect the increasing activity of granulosa cells rather than the endogenous activity of the oocyte. Evidence for protein synthesis by oocytes is nebulous and the ooplasm lacks polyribo- 
somes and contains a scattered endoplasmic reticulum. RNA is synthesized at various stages of development (Wasserman \& Letourneau, 1976), but evidence for the production of messenger RNA as opposed to other classes of RNA has yet to be obtained. Such observations question the role of the oocyte in initiating follicular growth.

Removal of the oocyte from its follicle is reported to result in immediate luteinization (El-Fouly, Cook, Nekola \& Nalbandov, 1970), and the presence of oocytes in cultures of granulosa cells inhibits luteinization in vitro (Nekola, Stoklosowa \& Nalbandov, 1971). Dictyate oocytes may thus inhibit follicular luteinization, an influence negated by their resumption of meiosis in response to LH. However, surgical interference with Graafian follicles without removing the oocytes can also induce luteinization in several species.

Several lines of evidence indicate that the granulosa cells control follicular development. In many species, meiosis is arrested and oocytes enter dictyotene in the fetal or neonatal ovary as they are enclosed by granulosa cells during the formation of the primordial follicle; those oocytes which evade granulosa cells continue meiosis to metaphase-II and become atretic (Ohno \& Smith, 1964). Proliferating granulosa cells appear to be controlled in a manner similar to that of other mitotic tissues, e.g. epithelia, haemopoietic and liver cells. Some resemblances with the haemopoietic system are very close, for example in migration of primordial germ cells and primary haemopoietic cells from their origin in the primitive streak or yolk sac (see Ritter, 1975). Follicle growth might be analysed in terms of mitotic regulation in granulosa cells, although the comparison is not strict for follicles obviously begin growth as a complete unit rather than as groups of individual cells. The terminal period of cytodifferentiation in epithelia and other systems, e.g. keratinization, could be represented by luteinization and the production of mucopolysaccharides in enlarging follicles. Chalones or other compounds influencing follicular growth remain to be identified; the initiation of growth in mouse follicles is impaired by fluid withdrawn from large bovine follicles (Peters et al., 1973), although this effect is apparently not mediated by specific proteins (Andersen, Krøll, Byskov \& Faber, 1976).

The endocrine activity of follicles could also indicate the importance of granulosa cells in controlling follicle growth. Our analyses of steroids in follicular fluid and observations on cultures of human granulosa cells (unpublished) indicate that these cells are involved in both aromatization and luteinization after injection of HCG. The changing levels of oestrogen during the follicular and luteal phases of the cycle could therefore reflect the activity of granulosa cells, exerted through the differentiation of gonadotrophin receptors. The relative lack of receptors in granulosa cells taken from hypophysectomized rats has been reported to prevent the full maturation of the oocyte in vitro (Erickson \& Ryan, 1976).

Observations on cystic and atretic follicles also imply that the granulosa cells determine the integrity of the follicle. In rats in persistent oestrus, administration of LH causes the cells surrounding the oocyte to become secretory and the oocyte to mature, but luteinization does not occur. The corona radiata and cumulus cells thus appear to control oocyte maturation, while the granulosa cells maintain the integrity of the follicle. Oocyte maturation is well known to occur in atretic follicles as the granulosa and corona radiata cells disperse.

\section{Changes in steroidogenesis as ovulation approaches}

A surge of LH at mid-cycle or an injection of HCG induces various types of changes in the endocrine activity of preovulatory follicles. The major effect of $\mathrm{LH}$ on steroidogenesis involves an increased conversion of cholesterol to pregnenolone, so making pregnenolone increasingly available for further conversions (Ichii, Forcheilli \& Dorfman, 1963; Koritz \& Hall, 1965; Hall \& Young, 1968; Armstrong, Lee \& Miller, 1970). Our data on the high levels of pregnenolone in the follicular fluid of preovulatory human follicles would support this contention.

Our results in rats indicate that $\mathrm{LH}$ also exerts another action, enhancement of the activity of $3 \beta$-steroid dehydrogenase and $\Delta^{5}$ isomerase. Each of the $\Delta^{5}$ substrates utilized was increasingly converted to its corresponding $\Delta^{4}$ product in the rat ovary after the LH surge, showing that the 
activation of these enzymes is a direct result of the LH surge. Increased $3 \beta-H S D$ activity could be achieved in several ways: the number of cells with $3 \beta$-HSD activity could increase, more substratemay become available, the concentration of co-factors could increase, or the amount of enzyme protein could rise. Significant changes in cell number are an unlikely explanation since $3 \beta-H S D$ activity increases during the afternoon of pro-oestrus during a period of about $6 \mathrm{~h}$ and the overall structureand number of cells in the ovary presumably changes very little during this time. Substrate availability was not a limiting factor in the present work, because excess substrate was added to the homogenate during the experiments. The increase in $3 \beta$-HSD activity after the LH surge is more likely to arise through an increased availability of co-factors or the induction or activation of enzyme proteins. Experiments are underway to test these possibilities.

Two types of follicle were present in the human ovary as ovulation approached after an injection of HCG in mid-cycle. They could be clearly identified, as shown by the complete coincidence between their classification at laparoscopy and by the cluster analysis of steroids in follicular fluid. One type of follicle was about to ovulate, whereas the other was still non-ovulatory. Preovulatory follicles were large and contained high concentrations of progesterone, 17 $\alpha$-hydroxyprogesterone and oestradiol17ß. These observations agree with earlier evidence in the human (Edwards et al., 1972; McNatty et $a l ., 1975)$ and the data in the rat described above showing that progesterone produced before ovulation is due to the response of the follicle to endogenous LH or HCG. The second type of follicle, smaller and non-ovulatory, contained larger amounts of $\Delta^{5}$ steroids and androgens. The $\Delta^{5}$ steroids may be diluted in preovulatory follicles through an increase in diameter from $\frac{1}{2} \mathrm{~cm}$ to $3 \mathrm{~cm}$, a 200 -fold dilution. The production of $\Delta^{5}$ steroids may be relatively constant during the menstrual cycle, in contrast to the fluctuating production of progesterone, $17 \alpha$-hydroxyprogesterone and oestradiol-17 $\beta$. This conclusion is consistent with measurements of the ovarian contribution to $\Delta^{5}$ steroids and androgens during the human menstrual cycle (Abraham, 1974b; Kim, Hosseinian \& Dupon, 1974). Alternatively, large preovulatory follicles may increasingly utilize $\Delta^{5}$ steroids for conversion to $\Delta^{4}$ steroids or aromatization as ovulation approaches, so decreasing their concentration in follicular fluid.

Tentative conclusions can be drawn from our data on transformations carried out by thecal and granulosa cells in the human ovary in response to HCG or a surge of LH. Steroids produced by the vascularized thecal cells may be transported more rapidly into plasma than those produced by the non-vascularized granulosa cells, because steroids in follicular fluid are released only showly into the circulation (Giorgi, Addis \& Colombo, 1969; YoungLai \& Short, 1970; Edwards, 1974). Species differences may exist as the rate of diffusion from sheep follicles cultured in vitro appears to be greater (Seamark, Moor \& Mclntosh, 1974). The high levels of progesterone and oestradiol-17 $\beta$ in human follicular fluid indicate that both hormones may be synthesized primarily by granulosa cells. Moreover, these cells convert androgens to oestrogens in culture, in addition to synthesizing progesterone and $17 \alpha$-hydroxyprogesterone (unpublished). Some of the oestradiol-17 $\beta$ produced in the follicular or luteal phase of the cycle could therefore arise from granulosa cells. This could explain the situation in neonatal and post-menopausal human ovaries lacking these cells, whereby conversions occur via the $\Delta^{5}$ pathway and androgens are synthesized, but conversions via the $\Delta^{4}$ pathway and aromatization are not found (Shenker, Polishuk \& Eckstein, 1971; Payne \& Jaffe, 1974). Thecal and granulosa cells may thus co-operate in steroidogenesis as initially proposed by Falck (1959). Nevertheless, thecal cells appear histologically more active when the synthesis of oestradiol is maximal, and granulosa cells display no ultrastructural indications of steroidogenic activity until just before ovulation (Baird, Baker, McNatty \& Neal, 1975; Amin et al., 1976).

\section{Defective follicular growth}

Various anomalous forms of follicular growth and luteinization occur in mammalian ovaries. Growth can be arrested at specific stages, leading to syndromes in which the accumulated follicles release androgens and other steroids as in human polycystic ovaries. Our observations would imply that these follicles are similar to the non-ovulatory Graafian follicles in human ovaries at mid-cycle, and they 
may have accumulated through the absence of feedback effects within the ovary from larger follicles.

The large cystic follicles containing a vesicular oocyte in rats in persistent oestrus are quite different, and have evidently progressed beyond the stage of maximal sensitivity to LH. Some follicles can still undergo ovulation in response to LH, but the response of others is restricted to secretion by corona cells and oocyte maturation. These observations are consistent with the finding that the various physiological systems in rat follicles sensitive to $\mathrm{LH}$, i.e. oocyte maturation, luteinization and follicular rupture, can be stimulated independently and display different thresholds for activation (Gosden, Everett \& Tyrey, 1976). The afternoon of pro-oestrus is the optimal time for rat follicles to receive an ovulation-inducing stimulus of $\mathrm{LH}$, and early or late exposure to the hormone may account for such partial responses. This unusual form of atresia evidently afflicts fully grown follicles, a situation perhaps arising through the availability of large amounts of FSH during follicle growth followed by a lack of LH. A comparable situation could arise in human ovaries in the monocystic ovary syndrome, or when the ovaries are stimulated by FSH during treatment with HMG or clomiphene. One example of this type of impaired follicular reactivity was evidently found after the injection of HCG into women in mid-cycle. Abnormal follicle growth may also arise through deficiencies in the hypothalamic pituitary axis, and deficiencies in hypothalamic catecholamines involved in the release of LH have been claimed to cause persistent oestrus and other forms of ovarian failure in ageing rats (Meites \& Huang, 1976). Similar situations may arise in women. More information is needed, however, on the role of factors such as prolactin in such disorders, because hyperprolactinaemia is also known to disturb ovarian activity in women.

Information on the longevity and fate of follicles in persistent oestrous rats is required: some of them appear unusually enlarged (cystic) with a thin membrana granulosa containing dividing cells, and they are comparable to the large follicles found in animals when the endogenous surge of gonadotrophins is blocked on successive days by barbiturates (Freeman, Butcher \& Fugo, 1970). This appearance suggests that the existing set of large follicles continues to grow when the ovulatory stimulus is arrested, a situation evidently differing from the polycystic ovary syndrome in women. If follicles do not persist in constant oestrous rats for at least 1 day they would have to be replaced unusually rapidly to maintain the characteristic follicular constitution of the ovaries. Perhaps the existing set of large follicles is not replaced synchronously, but each follicle is replaced individually as it reaches the end of its functional lifespan. More information is therefore needed to decide whether follicle growth is continuous, the transitions between stages being similar to those in normal ovaries, or whether large follicles persist for several days or longer and influence the growth and death rates of earlier stages.

Comparison of hormone profiles in persistent-oestrous rats and in women with polycystic ovaries reveals another difference. The latter usually have elevated levels of $\mathrm{LH}$ with low levels of FSH (De Vane, Czekala, Judd \& Yen, 1975; Rebar et al., 1976), virtually the converse of the persistent-oestrous condition. This abnormal profile in women could account for the arrest of follicle development, and the surgical reduction of the ovarian mass or other treatments applied to these patients may increase the secretion of gonadotrophins, even temporarily, and so alleviate the condition. We do not yet know whether circulating androgens are elevated in persistent-oestrous rats as in women with polycystic ovaries (De Vane et al., 1975).

The persistent-oestrous rat thus seems of limited value as a model for the polycystic ovary syndrome, but has potential significance for the study of another biological problem. The persistence of large follicles in such rats represents a period of preovulatory ageing of the oocyte distinct from other putative age changes resulting from gradients of oocyte formation in the developing ovary or from the accumulation of mutations during the prolonged dictyate phase. The normality of rat oocytes ovulated after so-called preovulatory or intrafollicular ageing has been extensively studied by Butcher (1975), who delayed ovulation by barbiturate injections or studied females with prolonged oestrous cycles. His conclusion that 'over-ripe' ova have reduced viability and are predisposed to chromosomal anomalies cannot be applied to persistent-oestrous rats until their rates of follicle growth and turnover have been determined. More information is also needed on follicular growth under the conditions described by Butcher (1975) before definite conclusions can be reached about the genetic consequences in oocytes. 


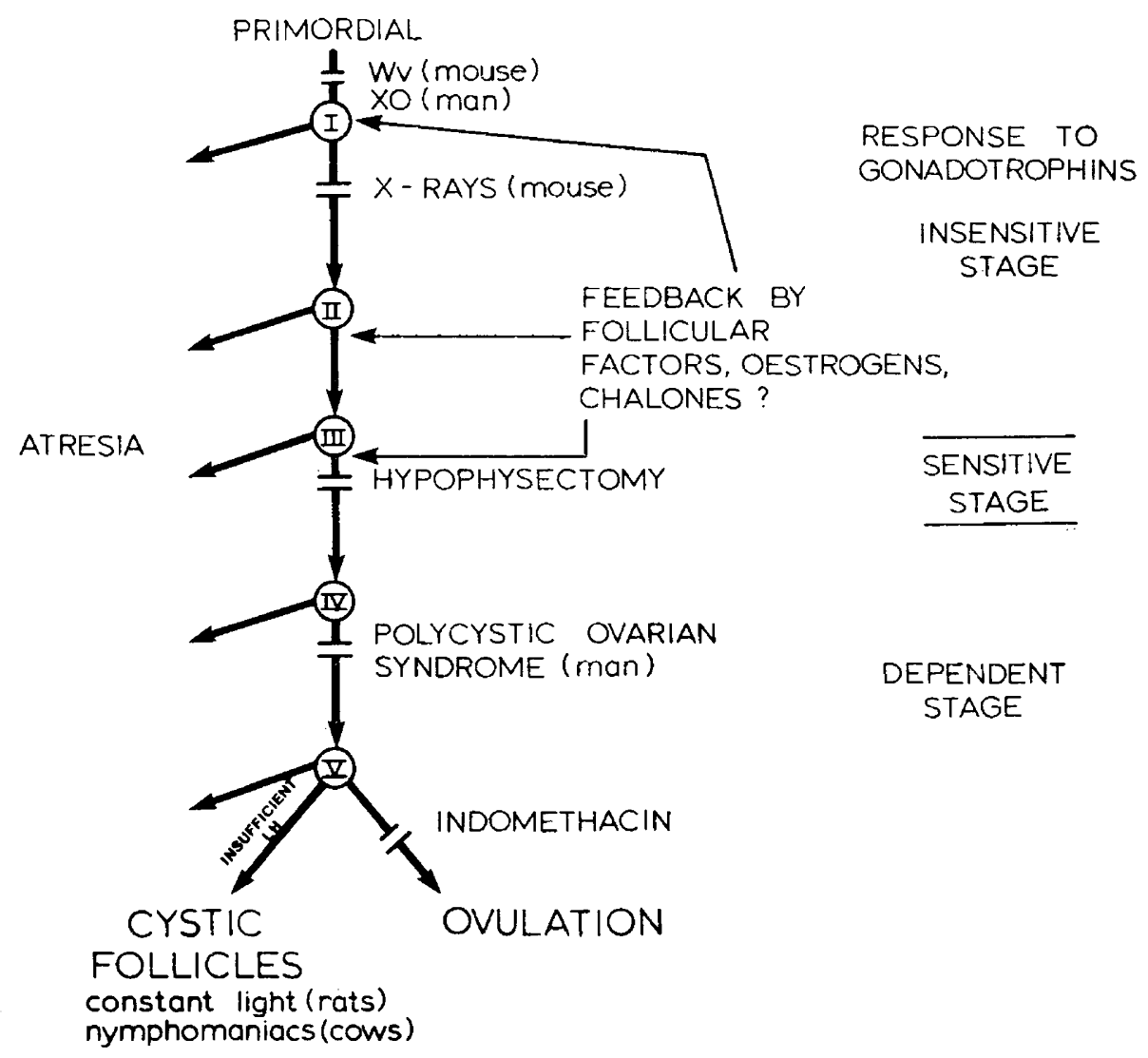

Text-fig. 11. A representation of defective ovarian conditions, showing their relationships to the stages of follicle growth.

We wish to conclude this review with a simple plan of follicular development from the primordial follicle to ovulation, indicating when various disorders arise (Text-fig. 11). Most of the syndromes indicated involve an inhibition of the growth of follicles. Inadequate gonadotrophic stimulation of preovulatory follicles results in the formation of follicular cysts which then become refractory to further stimulation, presumably as the number of LH receptors declines. The Stein-Leventhal syndrome affects an earlier stage of follicle growth, and hypophysectomy virtually blocks the formation of all antral follicles. We have also indicated the deficiency of primordial follicles arising in certain genetic situations, and how large numbers of primordial follicles are destroyed by ionizing radiations. A single example is given of treatments suppressing preovulatory changes in follicles, namely the inhibition of follicular rupture by indomethacin; other drugs are known to interfere with steroid biosynthesis at this time.

The possible influence of ovarian factors on the early stages of follicular growth is indicated. Some of these compounds, notably oestrogens, are obviously under the control of gonadotrophins, which may thereby indirectly influence these early stages of growth. We have not indicated any suppressive effects large Graafian follicles on their smaller neighbours, or of CL on follicles in the ipsilateral ovary, since such effects remain speculative.

We thank the Ford Foundation, the Medical Research Council, the Trustees of the Queen Elizabeth II British Columbia Centennial Scholarship, the Wellcome Trust, Miss Lillian Howells, and the Manchester Area Health Authority for their kindness in supporting these studies, and Dr G. E. Abraham for kindly providing all the antibodies used in the radioimmunoassays. 


\section{References}

Abercrombie, M. (1946) Estimation of nuclear population from microtome sections. Anat. Rec. 94, 239247.

Abraham, G.E. (1974a) Radioimmunoassay of steroids in biological materials. Acta endocr., Copenh. 75, Suppl. 183, 1-42.

Abraham, G.E. (1974b) Ovarian and adrenal contribution to peripheral androgens during the menstrual cycle. J. clin. Endocr. Metab. 39, 340-346.

AMIN, H., RichaRT, R.M. \& BRINSON, A.O. (1976) Preovulatory granulosa cells and steroidogenesis. An ultrastructural study in the Rhesus monkey. Obstet. Gynecol., N.Y. 47, 562-568.

Andersen, M.M., Krøll, J., Byskov, A.G. \& FAber, M. (1976) Protein composition in the fluid of individual bovine follicles. J. Reprod. Fert. 48, 109-118.

Armstrong, D.T., LeE, T.P. \& Miller, L.S. (1970) Stimulation of progesterone biosynthesis in bovine corpora lutea by luteinizing hormone in the presence of an inhibitor of cholesterol synthesis. Biol. Reprod. 2, 29-36.

Baird, D.T., Baker, T.G., McNatty, K.P. \& Neal, P. (1975) Relationship between the secretion of the corpus luteum and the length of the follicular phase of the ovarian cycle. J. Reprod. Fert. 45, 611-619.

BAKER, T.G. (1972) Oogenesis and ovarian development. In Reproductive Biology, pp. 398-437. Eds H. Balin \& S. Glasser. Excerpta Medica, Amsterdam.

Beaumont, H.M. \& MANDL, A.M. (1962) A quantitative and cytological study of oogonia and oocytes in the foetal and neonatal rat. Proc. $R$. Soc. B 155, 557-579.

BLock, E. (1952) Quantitative morphological investigations of the follicular system in women. Variation at different ages. Acta anat. 14, 108-123.

Brambell, F.W.R. (1928) The development and morphology of the gonads of the mouse. Part III. The growth of the follicles. Proc. R. Soc. B 103, 258-272.

Bullough, W.S. (1973) The chalones: a review. Nat. Cancer Inst. Monogr. 38, 5-18.

BuTCHER, R.L. (1975) Role of intrauterine environment and intrafollicular aging of the oocyte on implantation rates and development. In Aging Gametes. Their Biology and Pathology, pp. 201-208. Ed. R. J. Blandau. S. Karger, Basel.

Clermont, Y. \& Mauger, A. (1976) Effect of a spermatogonial chalone on the growing rat testis. Cell Tissue Kinetics 9, 99-104.

DaAne, T.A. \& Parlow, A.F. (1971) Periovulatory patterns of rat serum follicle stimulating hormone luteinizing hormone during the normal estrous cycle. Effects of pentobarbital. Endocrinology 88, 653-663.

Delahunt, J.W., Clements, R.V., Ramsay, I.D., Newton, J., Collins, W.P. \& LANdon, J. (1975) The monocystic ovary syndrome. Br. med.J. 4, 621-622.

De Vane, G.W., Czekala, N.M., Judd, H.L. \& Yen, S.S.C. (1975) Circulating gonadotropins, estrogens, and androgens in polycystic ovarian disease. $\mathrm{Am} . J$. Obstet. Gynec. 121, 496-500.

Dullaart, J., Kent, J. \& Ryle, M. (1975) Serum gonadotrophin concentrations in infantile female mice. J. Reprod. Fert. 43, 189-192.
EDwards, R.G. (1974) Follicular fluid. J. Reprod. Fert. 37, 189-219.

Edwards, R.G. \& Steptoe, P.C. (1974) Control of human ovulation, fertilization and implantation. Proc. R. Soc. Med. 67, 932-936.

EDWaRds, R.G. \& STEPTOE, P.C. (1975) Induction of follicular growth, ovulation and luteinization in the human ovary. J. Reprod. Fert., Suppl. 22, 121-163.

Edwards, R.G., Steptoe, P.C., Abraham, G.E., Walters, E., Purdy, J.M. \& Fotherby, K. (1972) Steroid assays and preovulatory follicular development in human ovaries primed with gonadotrophins. Lancet ii, 611-615.

El-Fouly, M.A., Cook, B., Nekola, M. \& Nalbandov, A.V. (1970) Role of the ovum in follicular luteinization. Endocrinology, 87, 288-293.

Erickson, G.F. \& RYAN, K.J. (1976) Spontaneous maturation of oocytes isolated from ovaries of immature hypophysectomized rats. J. exp. Zool. 195, 153-158.

EVERETT, J.W. (1964) Central neural control of reproductive functions of the adenohypophysis. Physiol. Rev. 44, 373-431.

FADDY, M.J. (1976) A note on the general time-dependent stochastic compartmental model. Biometrics (in press).

FAdDy, M.J., Jones, E.C. \& Edwards, R.G. (1976) An analytical model for ovarian follicle dynamics. $J$. exp. Zool. (in press).

FALCK, B. (1959) Site of production of oestrogen in rat ovary as studied in microtransplants. Acta physiol. scand. 47, Suppl. 163, 1-101.

Ferin, J., Thomas, K. \& Johansson, E.D.B. (1973) Ovulation detection. In Human Reproduction, Conception and Contraception, pp. 260-283. Eds E. S. E. Hafez \& T. N. Evans. Harper \& Row, Hagerstown.

FowLER, R.E. \& EDWARds, R.G. (1973) The genetics of early human development. Prog. med. Genet. 9, 49-112.

Fowler, R.E., Chan, S.T.H., Edwards, R.G., StePTOE, P.C. \& WALTERS, D.E. (1977) Steroidogenesis in human follicles approaching ovulation as judged from assays of follicular fiuid. J. Endocr. 72, 259-271.

Freeman, M.E., BuTcher, R.L. \& Fugo, N.W. (1970) Alteration of oocytes and follicles by delayed ovulation. Biol. Reprod. 2, 209-215.

Grorgl, E.P. (1963) The determination of steroids in cyst fluid from human polycystic ovaries. J. Endocr. 27, 225-240.

Giorgi, E.P., Adpis, M. \& Colombo, G. (1969) The fate of free and conjugated oestrogens injected into the Graafian follicles of equines. J. Endocr. 45, 37-50.

Goldenberg, R.L., Vaitukaitis, J.L. \& Ross, G.T. (1972) Estrogen and follicle stimulating hormone interactions on follicle growth in rats. Endocrinology 90, 1492-1498.

GoldenberG, R.L., Reiter, E.O. \& Ross, G.T. (1973) Follicle response to exogenous gonadotropins: an estrogen-mediated phenomenon. Fert. Steril. 24, $121-125$.

Gosden, R.G., EveretT, J.W. \& Tyrey, L. (1976) 
Luteinizing hormone requirements for ovulation in the pentobarbital-treated proestrous rat. Endocrino$\log y$ 99, 1046-1053.

GrimeK, H.J., Nuti, L.C., Nuti, K.M. \& McShan, W.H. (1976) Effect of neuraminidase treatment on the biological activity of highly purified ovine FSH and $\mathrm{LH}$ in hypophysectomized immature male and female rats. Endocrinology 98, 105-110.

Hall, P.F. \& Young, D.G. (1968) Site of action of trophic hormones (ACTH;ICSH) upon the biosynthetic pathways to steroid hormones. Endocrinology 82, 559-568.

Harman, S.M., LouveT, J.-P. \& Ross, G.T. (1975) Interaction of estrogen and gonadotropins on follicular atresia. Endocrinology 96, 1145-1152.

HAY, M.F. \& MOOR, R.M. (1975) Distribution of $\Delta^{5}-3 \beta$ hydroxysteroid dehydrogenase activity in the Graafian follicle of the sheep. J. Reprod. Fert. 43, 313-322.

HeNDERSON, S.A. (1970) The time and place of meiotic crossing-over. A. Rev. Genet. 4, 295-324.

Henderson, S.A. \& Edwards, R.G. (1968) Chiasma frequency and maternal age in mammals. Nature, Lond. 218, 22-28.

ICHII, S., ForChIELlI, E. \& DORFMAN, R.I. (1963) In vitro effect of gonadotrophins on the soluble cholesterol side-chain cleaving enzyme system of bovine corpus luteum. Steroids 2, 631-656.

INGRAM, D.L. (1953) The effect of hypophysectomy on the number of oocytes in the adult albino rat. $J$. Endocr. 9, 307-311.

Jones, E.C. \& KroHN, P.L. (1961a) The relationships between age, numbers of oocytes and fertility in virgin and multiparous mice. $J$. Endocr. 21, 469-495.

Jones, E.C. \& KROHN, P.L. (1961b) The effect of hypophysectomy on age changes in the ovaries of mice. J. Endocr. 21, 497-509.

Kim, M.H., Hosseinian, H. \& Dupon, C. (1974) Plasma levels of estrogens, androgens and progesterone during normal and dexamethasone-treated cycles. J. clin. Endocr. Metab. 39, 706-712.

Koritz, S.B. \& Hall, P.F. (1965) Further studies on the locus action of interstitial cell-stimulating hormone on the biosynthesis of progesterone by bovine corpus luteum. Biochemistry, N. Y. 4, 2740-2747.

Krarup, T., Pedersen, T. \& Faber, M. (1969) Regulation of oocyte growth in the mouse ovary. Nature, Lond. 224, 187.

MCNatty, K.P., Hunter, W.M., MCNeilly, A.S. \& SAWERS, R.S. (1975) Changes in the concentration of pituitary and steroid hormones in the follicular fluid of human Graafian follicles throughout the menstrual cycle. $J$. Endocr. 64, 555-571.

MANDL, A.M. \& ZuCKERMAN, S. (1951) The relation of age to numbers of oocytes. J. Endocr. 7, 190-193.

Meites, J. \& Huang, H.H. (1976) Relation of the neuroendocrine system to loss of reproductive function in aging rats. In Neuroendocrine Regulation of Fertility, pp. 246-258. Ed. T.C. Anand Kumar. S. Karger, Basel.

Mintz, B. \& Russell, E.S. (1957) Gene-induced embryological modifications of primordial germ cells in the mouse. J. exp. Zool. 134, 207-237.

Mizejewski, G.J. (1976) Studies of human chorionic gonadotrophin in steroid-primed hypophysectomized rats. Acta endocr., Copenh. 82, 801-808.

MotTA, P. \& Bourneva, V. (1970) A comparative histochemical study of $\Delta^{5}-3 \beta$-hydroxysteroid dehydrogenase and lipid content in the rat ovary with special reference to the interstitial cells. Acta histochem. 38, 340-351.

Naftolin, F., Brown-Grant, K. \& Corker, C.S. (1972) Plasma and pituitary luteinizing hormone and peripheral plasma oestradiol concentrations in the normal oestrous cycle of the rat and after experimental manipulation of the cycle. J. Endocr. 53, $17-30$.

Nekola, M.V., Stoklosowa, S. \& Nalbandov, A.V. (1971) Effect of the ovum on the morphology of follicular cells. Anat. Rec. 169, 387.

Nuti, L.C., McShan, W.H. \& Meyer, R.K. (1974) Effect of ovine FSH and LH on serum steroids and ovulation in hypophysectomised immature female rats. Endocrinology 95, 682-689.

OHNo, S. \& Sмітh, J.B. (1964) Role of fetal follicular cells in meiosis of mammalian oocytes. Cytogenetics 3, 324-333.

Pavic, D. (1963) The effect of gonadotrophic hormones on young rat ovaries grown in organ culture. $J$. Endocr. 26, 531-538.

PAYNe, A.H. \& JAfFe, R.B. (1974) Androgen formation from pregnenolone sulfate by the human fetal ovary. J. clin. Endocr. Metab. 39, 300-304.

Pedersen, T. (1972) Follicle growth in the mouse ovary. In Oogenesis, pp. 361-376. Eds J. D. Biggers \& A. W. Schuetz. University Park Press, Baltimore.

Pedersen, T. \& Peters, H. (1968) Proposal for a classification of oocytes and follicles in the mouse ovary. J. Reprod. Fert. 17, 555-557.

Peters, H., Byskov, A.G. \& Faber, M. (1973) Intraovarian regulation of follicle growth in the immature mouse. In The Development and Maturation of the Ovary and its Functions, pp. 20-23. Ed. H. Peters. Excerpta Medica, Amsterdam.

Pupkin, M., Bratt, H., Weisz, J., Lloyd, C.W. \& BALOGH, K. (1966) Dehydrogenases in the rat ovary. 1. A histochemical study of $\Delta^{5}-3 \beta$ and $20 \alpha$-hydroxysteroid dehydrogenases and enzymes of carbohydrate oxidation during the estrous cycle. Endocrino$\log y$ 79, 316-327.

ReADHEAD, C. \& ABRahaM, G.E. (1977) The relation of circulating steroids to $\Delta^{5}-3 \beta$-hydroxysteroid dehydrogenase enzymatic activity in the rat ovary throughout the oestrous cycle. (in preparation).

RebaR, R., JUdD, H.L., YeN, S.S.C., RAKOFF, J., VANDENBERG, G. \& Naftolin, F. (1976) Characterization of the inappropriate gonadotropin secretion in polycystic ovary syndrome. J. clin. Invest. 57, 1320-1329.

RITTER, M.A. (1975) Early differentiation of the lymphoid system. In The Early Development of Mammals, pp. 359-372. Eds M. Balls \& A. E. Wild. Cambridge University Press.

Samuels, L.T., Helmreich, M.L., Lasater, M.B. \& REICH, H. (1951) An enzyme in endocrine tissues which oxidizes $\Delta^{5}-3$ hydroxysteroids to $\alpha, \beta$ unsaturated ketones. Science, N.Y. 113, 490-491.

Schenker, J.G., Polishuk, W.Z. \& Eckstein, B. (1971) 
Pathways in the biosynthesis of androgens in the post-menopausal ovary in vitro. Acta endocr., Copenh. 325-332.

Seamark, R.F., Moor, R.M. \& McIntosh, J.E.A. (1974). Steroid hormone production by sheep ovarian follicles cultured in vitro. J. Reprod. Fert. 41, 143-158.

SHORT, R.V. (1964) Ovarian steroid synthesis and secretion in vivo. Recent Prog. Horm. Res. 20, 303340.

Singh, R.P. \& CARR, D.H. (1966) The anatomy and histology of XO human embryos and fetuses. Anat. Rec. 155, 369-384.

Wallace, M.E., MacSwiney, F.J. \& Edwards, R.G. (1976) Parental age and recombination frequency in the house mouse. Genet. Res. 28, 241-251.

WARD, J.H. (1963) Hierarchical groups to optimise an objective function. $J$. Am. Statist. Ass. 58, 236-244.

Wasserman, P.M. \& Letourneau, G.E. (1976) RNA synthesis in fully-grown mouse oocytes. Nature, Lond. 261, 73-74.
WATtenberG, L.W. (1958) Microscopic histochemical demonstration of steroid $3 \beta-\alpha$ dehydrogenase in tissue sections. J. histochem. Cytochem. 6, 225-232.

WeIBEL, E.R. (1973) Stereological techniques for electron microscopic morphometry. In Principles and Techniques of Electron Microscopy, Biological Applications, Vol. 3, pp. 237-285. Ed. M.A. Hayat. Van Nostrand Reinhold Company, New York.

Younglai, E.V. \& ShorT, R.V. (1970) Pathways of steroid biosynthesis in the intact Graafian follicle of mares in oestrus. J. Endocr. 47, 321-331.

ZAMBONI, L. (1974) Fine morphology of the follicle wall and follicle cell-oocyte association. Biol. Reprod. 10, 125-149.

ZelezNik, A.J., Midgley, A.R., JR. \& Reichert, L.E., $J_{R}$ (1974) Granulosa cell maturation in the rat: increased binding of human chorionic gonadotropin following treatment with follicle-stimulating hormone in vivo. Endocrinology 95, 818-825.

ZUCKERMAN, S. (1951) The number of oocytes in the mature ovary. Recent Prog. Horm. Res. 6, 63-109. 